
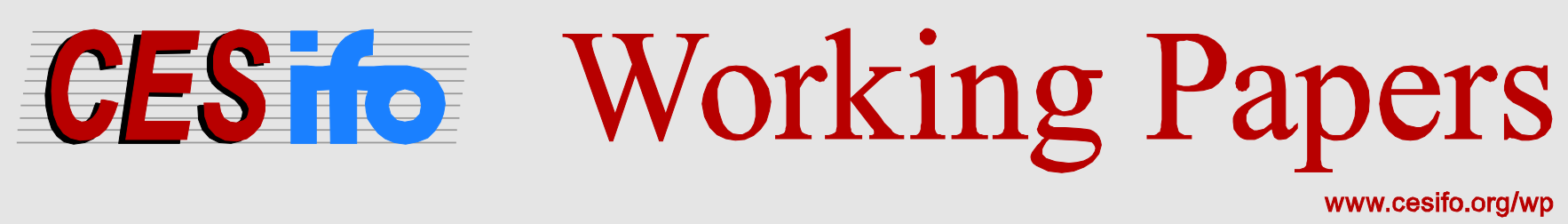

\title{
Is the Italian Public Debt Really Unsustainable? An Historical Comparison (1861-2010)
}

\author{
Silvana Bartoletto \\ Bruno Chiarini \\ Elisabetta Marzano
}

\author{
CESIFO WORKING PAPER NO. 4185 \\ Category 6: Fiscal Policy, Macroeconomics and Growth \\ APRIL 2013
}

An electronic version of the paper may be downloaded

- from the SSRN website:

- from the RePEc website:

- from the CESifo website:

WWW.SSRN.com

www.RePEc.org

www.CESifo-group.org/wp

\section{CESifo}




\title{
Is the Italian Public Debt Really Unsustainable? An Historical Comparison (1861-2010)
}

\begin{abstract}
The aim of this paper is to analyze the sustainability of public debt in Italy during the last 150 years (1861-2010) by employing a database containing several statistical novelties: new time series estimates of public debt and GDP (respectively Bank of Italy and Baffigi, 2011) and an original reconstruction of the revenues of the State. The key economic indicators analyzed include public debt, primary and total deficits, nominal and real GDP rates of growth. Longterm analysis of new homogeneous statistical series has led to a different perspective, in particular when compared with the existing Italian literature on the debt-to-GDP ratio. Two main issues are addressed. First, we examine the size and dynamics of public finance aggregates in a long-term perspective. In particular, we carry out a detailed historical analysis, aiming to identify the determinants of public debt and its ratio to GDP. Second, following the approach proposed both by Bohn $(1998,2005)$ and Doi et al. $(2011)$, we test for the sustainability of public debt in Italy, comparing four different historical periods.
\end{abstract}

JEL-Code: C220, E620, H600, N130, N140, N230, N240.

Keywords: public debt sustainability, Italian debt history, intertemporal budget constraint, fiscal rule.

\author{
Silvana Bartoletto \\ Department of Economic and Legal Studies \\ University of Naples Parthenope \\ Italy-80132 Naples \\ silvana.bartoletto@uniparthenope.it
}

Bruno Chiarini

Department of Economic and Legal Studies

University of Naples Parthenope

Italy - 80132 Naples

chiarini@uniparthenope.it
Elisabetta Marzano

Department of Economic and Legal Studies

University of Naples Parthenope

Italy-80132 Naples

elisabetta.marzano@uniparthenope.it

We thank participants at the Conference of the Italian Economists Society (SIE) held in Rome in October 2011 and participants at the 2012 CESifo Area Conference on Public Sector Economics held in Munich in April 2012. We gratefully acknowledge the funding from PRIN 2008, "Tax evasion, irregular employment and corruption: cyclical features and structural problems”. Usual disclaimers apply. 


\section{Introduction}

One of the greatest issues in Italian macroeconomic performance since the birth of the Italian State has been the extraordinary fluctuation in the public debt ratio. This statement sounds somewhat unusual if we consider recent decades, but long-term analysis of Italian finances shows that various phases of imbalance and rebalancing of accounts have followed one another: from 1990's to the present the debt-to-GDP ratio is comparable to the levels reached at the end of the $19^{\text {th }}$ century.

The empirical literature focuses on testing the sustainability of the intertemporal budget constraint through the use of univariate and multivariate techniques, with particular attention to issues relating to the presence of unit roots and fiscal rules. In this context, the articles by Bharat Trehan and Carl Walsh (1988), Henning Bohn (1998) can be considered among the most influential in the analysis of sustainability.

In this work, using the time-series approach, we intend to assess the sustainability of the fiscal policy in Italy using a much larger sample than those examined so far, covering the period 1861-2011. The use of a long sample, covering widely divergent historical periods, first requires thorough analysis of the events that have characterized different historical moments. Long-term analysis also required a considerable effort in the research and collation of data. With regard to public debt, we used the new series reconstructed by the Bank of Italy (Maura Francese and Angelo Pace, 2008), which distinguishes the various components of the General Government sector and offers insights into the issue of national debt, focusing on Central Government (for more details on data sources see the Appendix ). As to State revenues, we were able to reconstruct the entire time series for the period 1861-2011, analyzing the balance-sheets of the State General Accounting Department (Ragioneria Generale dello Stato, hereinafter RGS). This reconstruction was important because it allowed us to calculate for each year deficits and surpluses of the State budget. For public expenditures, the source of the data is the new historical series published recently by RGS (2011). Another aspect of our work is the analysis of primary deficit with and without military spending, which is usually not analyzed. Finally, as to the time series of nominal GDP, in the present paper we decided to employ the recent reconstruction by Alberto Baffigi (2011), covering the full sample, 1861-2011. As far as we know, our paper is the first to examine debt sustainability in Italy using a unique source of data for GDP: in previous works, in the analysis of the debt-to-GDP ratio, different series were used for different periods of time. ${ }^{1}$ Besides, some of these studies used the ISTAT series, whose publications showed evident weaknesses, 
particularly for the 1861-1913 period. ${ }^{2}$ It should be stressed that our results, based on Baffigi's reconstruction, differ massively from those of scholars who continue to employ ISTAT series.

The paper is organized as follows. The next Section identifies a broad pattern in the behavior of debt-to-GDP ratio, showing that there is considerable variation in the debt-to-GDP dynamic, with long waves suggesting that economic and political forces have been at work differently over the various historical phases of the sample. For each of these phases it is provided a detailed historical analysis, describing the key economic variables, political events and economic shocks which have impinged on the dynamic of GDP and debt. After this historical reconstruction, we display the results obtained proposing a modified version of the policy reaction function à la Bohn $(1998,2005)$ to test the sustainability of public debt. Based on the estimated fiscal rule for each historical period, we draw some policy implications: placing contemporary experience of high debt level in its historical context helps us to recognize analogies and precedents which, in turn, can lead to better management of present fiscal policy. The last Section concludes the paper and an Appendix reports the sources of the data.

\section{Italian debt in a long-term perspective}

From graphical inspection of the Italian debt-to-GDP ratio during the last 150 years, shown in Figure 1, we can identify several key issues.

Figure 1: the ratio of public debt (Central Government) to GDP (1861-2011)

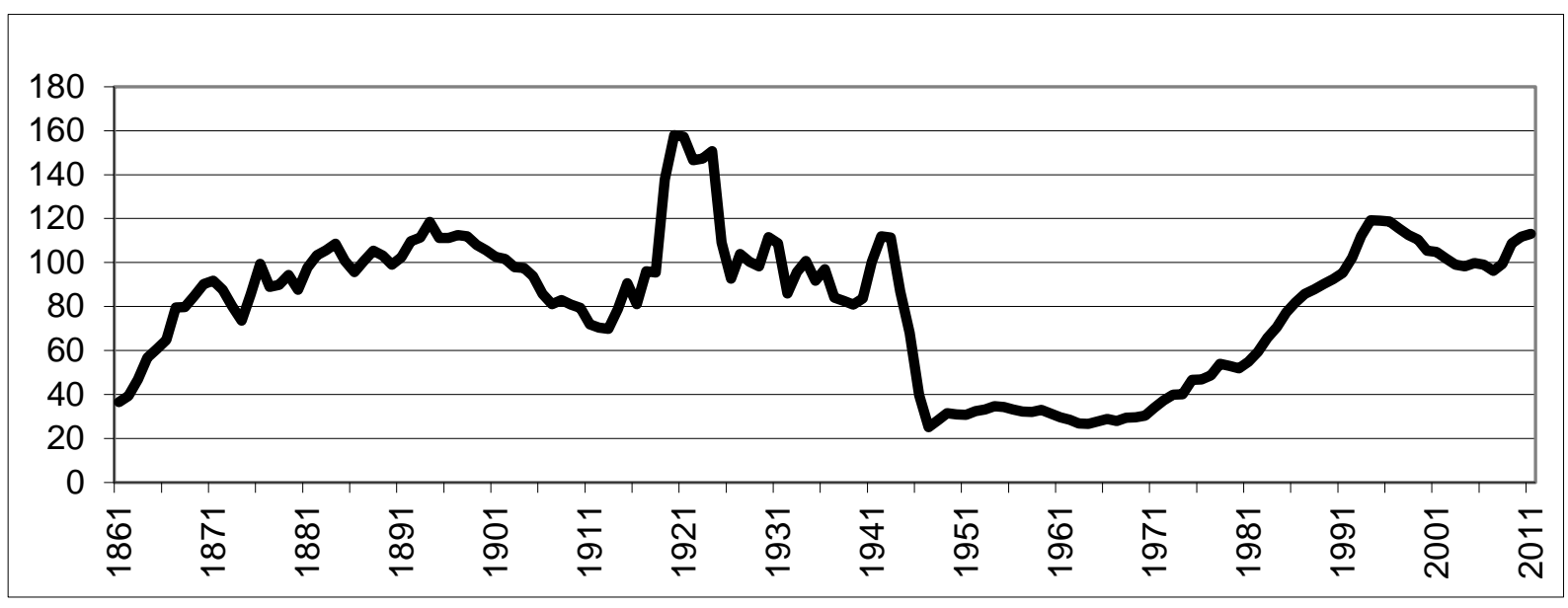

Sources: Data taken from Francese and Pace (2008), Baffigi (2011).

First, since the early years of the new Italian Kingdom, the public debt has absorbed much of GDP, with a debt-to-GDP ratio amounting to 37\% in 1861 due to the high debt of Italy's pre-Unification states and 
kingdoms. Second, throughout the study period the debt-to-GDP ratio was on average about $82 \%$, with two large peaks observed in the late 19th and 20th centuries. The burden of public debt in Italy observed in the 1990s was comparable to the levels reached during the last two decades of the 19th century: from 1993 to 2011, the debt-to-GDP ratio was on average about $107 \%$, slightly higher than the level reached from 1876 to 1899. ${ }^{3}$ Finally, there is a cyclical pattern in the debt/GDP ratio, with long waves of recovery and reduction. A synthesis of the variables impinging on the dynamic of indebtedness is provided in Table 1, distinguishing four main phases characterizing the debt-to-GDP ratio. ${ }^{4}$ During the first period, 1861-1913, we observe a complete cycle, with the rising phase from 1861 until the peak reached in 1894, almost 118\%. The subsequent declining phase lasts until 1913, when a new bottom peak is observed, amounting to $70 \%$. In the second phase, 1914-1945, the two World Wars had immediate effects on the dynamic of the public debt. However, the debt dynamics are very different in the two post-war periods, as will be analyzed in depth in the sections below. WWI caused a jump in the debt-to-GDP ratio, peaking at 158\% in 1920, in the postwar period (global maximum, see Table 1). The decline started only in the mid 1920s (in 1925 the debt-to-GDP had fallen to 109\%), and lasted for approximately 15 years, with a level of $81 \%$ in 1939 . The outbreak of WWII caused a new recovery in the dynamic of debt, peaking at $112 \%$ in 1942 . Subsequent hyperinflation allowed the debt-to-GDP ratio to fall by $40 \%$ in only three years, reaching a minimum of about $68 \%$ in 1945 (see Table 1). As to the third period, 1946 opened a phase of unusually low levels of debt-to-GDP ratio, with a strong reduction and a minimum peak of $25 \%$ reached in 1947, after which the debt stabilised around an average of about 31\% (global minimum, see Table 1). This favourable performance of the public imbalances was explained by two main facts: first, the flattering economic growth experienced during the period, which is usually referred to as the “economic boom” period (1953-’68); second, the conduct of fiscal policy, which was characterized by falling deficits until the early 1960s, with the average total deficit amounting to less than 3\% of GDP (see Table 1). During the latter phase 1971-2010, the Italian public debt rose sharply from 34\% in 1974 to about 119\% in the mid 1990s (Table 1). The increasingly large deficits observed during the 1980s generated considerable concern. The restrictive fiscal policies started in the early 1990s, and pursued in the decade after, were just sufficient to ensure the stabilization of debt, lowering it from $119 \%$ in 1994 to 96\% in 2007. However, the recent financial and economic crises and the current crisis of the sovereign debts have caused a resurgence in the dynamic of the Italian debt (as in other countries). Among the main causes 
of the difficulties experienced in debt management in recent decades is the very high burden of interest payment, on average 6\% of GDP, the largest share experienced since Unification.

Table 1 Public debt/GDP, primary deficit, interest spending, real GDP rate of growth, inflation rate (1862-2010)

\begin{tabular}{|c|c|c|c|c|c|}
\hline & & $1862-1913$ & 1914-1945 & 1946-1970 & 1971-2010 \\
\hline Public debt/GDP & Mean & 90.8 & 104.6 & 30.7 & 83.7 \\
\hline \multirow[t]{3}{*}{ (Central Government) } & Min & $39.3(1862)$ & $67.9(1945)$ & $25.1(1947)$ & 33.9 (1971) \\
\hline & Max & 118.5 (1894) & $158.0(1920)$ & 39.7 (1946) & 119.3 (1994) \\
\hline & St. Dev. & 17.4 & 24.5 & 3.1 & 27.2 \\
\hline Primary Deficit/GDP & Mean & -3.2 & 7.3 & 1.7 & 1.34 \\
\hline \multirow[t]{3}{*}{ (State Budget) } & Min & $-5.3(1879)$ & $-4.1(1925)$ & $-0.6(1961)$ & $-10.1(1997)$ \\
\hline & Max & $2.3(1862)$ & $23.9(1916)$ & $7.4(1946)$ & 8.7 (1987) \\
\hline & St. Dev. & 1.7 & 9.6 & 2.1 & 4.4 \\
\hline Interest spending/GDP & Mean & 3.9 & 3.3 & 1.0 & 5.9 \\
\hline \multirow[t]{3}{*}{ (State Budget) } & Min & $1.6(1862)$ & 0.7 (1945) & 0.7 (1964) & $0.96(1971)$ \\
\hline & Max & 4.9 (1894) & $5.9(1933)$ & $1.3(1956)$ & 11.4 (1993) \\
\hline & St. Dev. & 0.9 & 1.1 & 0.2 & 2.9 \\
\hline Real GDP rate of growth & Mean & 1.6 & -0.3 & 8.2 & 2.08 \\
\hline \multirow[t]{3}{*}{ (2010 market prices) } & Min & $-7.8(1867)$ & $-19.3(1944)$ & 3.7 (1954) & $-5.2(2009)$ \\
\hline & Max & $6.8(1865)$ & 9.9 (1937) & $35.0(1946)$ & $7.1(1973,1976)$ \\
\hline & St. Dev. & 2.2 & 6.8 & 6.3 & 2.3 \\
\hline Inflation rate & Mean & 0.6 & 18.0 & 8.5 & 8.12 \\
\hline \multirow[t]{3}{*}{ (GDP deflator) } & Min & $-14.7(1875)$ & $-10.5(1927)$ & $-2.7(1949)$ & 1.8 (1999) \\
\hline & Max & 11.4 (1873) & $142.6(1944)$ & $66.2(1946)$ & $20.8(1980)$ \\
\hline & St. Dev. & 4.8 & 33.3 & 17.0 & 6.19 \\
\hline
\end{tabular}

Source: data from Francese and Pace (2008) for national debt; Baffigi (2011) for GDP; RGS (2011) for revenues and expenses. The inflation index is calculated upon the GDP deflator, based on Baffigi (2011).In brackets the year of the peak.

In the next four Sections we will examine each single phase sketched above.

The first wave of public debt: 1861-1913 
From Unification until the eve of World War I, two figures seem to deserve special attention: the weight of public debt on GDP was on average 91\% (see Table 1) and the average ratio of primary deficit to GDP during the whole period was negative, i.e. the State Budget recorded a primary surplus. The period in question witnessed many political and economic events that have shaped the dynamic of public finance and growth. In particular, we should distinguish the period of right-wing power (1861-1876) from the left-wing and Giolitti periods.

\section{Right-wing economics (1861-1876)}

During this period, output growth remained well below the average recorded in the advanced European economies, with a growth rate of $1.2 \%$ a year. Slow economic growth, heavy fiscal pressure and high national debt were the main features of the "new Kingdom of Italy” (Marcello De Cecco, 1990). After Unification, the debts inherited from the constituent (pre-Unification) States had been merged and transformed into the new kingdom's public debt. According to the recent reconstruction by the Bank of Italy (Francese and Pace, 2008) of the debt series, and by Baffigi (2011) of the GDP, the stock of debt amounted to $37 \%$ of Italian GDP. ${ }^{5}$ High nominal and real debt interest rates, together with a low GDP growth rate, kept the ratio of Italian debt to GDP high throughout the period. ${ }^{6}$

In just five years, from 1861 to 1866, the national debt had more than tripled, from 1 to 3.3 million current euros. The creation of unified infrastructures and railways and the war against Austria in 1866 contributed to the strong growth of budget deficits. By 1867 the debt had reached $80 \%$ of GDP, mainly held by French nationals. When war with Austria became imminent, the Italian Prime Minister in vain asked the Rothschilds to assist with a new debt issue. ${ }^{7}$ The repatriation of much of the Italian debt held by French nationals worsened the situation, accelerating the collapse of the price of Italian rent ( "rendita Italiana”) in Paris, and deprived Italy of much of its metallic currency. The year 1866 was very difficult for Italian finances. The diminished confidence in financial markets had a negative impact on foreign investment, and the price of the consol fell from 64 in 1865 to 41 in June 1866. The tensions in the bond market, along with the drain of metal reserves (on 1 May 1866), associated with the financing of the war against Austria, led the Minister of Finance Scialoja to decree the inconvertibility of paper money (corso forzoso). ${ }^{8}$ To find new sources of revenue, the government decided to privatize land and railways and to issue new debt, to which it was compulsory for Italian citizens, according to their tax liabilities, to subscribe (prestito redimibile forzoso).$^{9}$ In 
addition, under government pressure, the purchases of government bonds by the Banca Nazionale, the largest bank of issue, peaked in $1866 .^{10}$

High interest rates further increased the deficit. During the period 1861-1875, the spread between Italian and foreign bonds remained very large: the average interest rate on long-term government bonds stood at 7.5\%, more than double that of England (3.3\%) (Pierluigi Ciocca, 2007). The lack of a central bank made it difficult to manage monetary and financial policies. Several banks could legally issue notes and held metallic reserves, since Italy did not develop a single monetary authority until $1926 .{ }^{11}$

Public debt on GDP was on average about $73 \%$ during the entire period (1862-1875), though it exceeded $92 \%$ in $1871 .{ }^{12}$ After 1871 , a gradual but steady reduction reversed the trend of the debt series but, as Figure 2 shows, there followed a substantial jump of the public debt/GDP ratio from about 74 in 1874 to $99 \%$ in 1876, the latter mainly caused by the dynamic of the nominal GDP. Actually, the strong contraction in the Italian economy, with the real GDP rate of growth declining from $5.7 \%$ in 1874 to -1.9 in 1876 , entailed a substantial deflationary process that reduced the inflation rate from $-3.7 \%$ in 1874 to $-14.7 \%$ in 1875 , and generated considerable disequilibrium in public finances.

Figure 2: public debt (left) and final revenues and outlays (right), proportion of GDP, 1861-1913 (percentage)
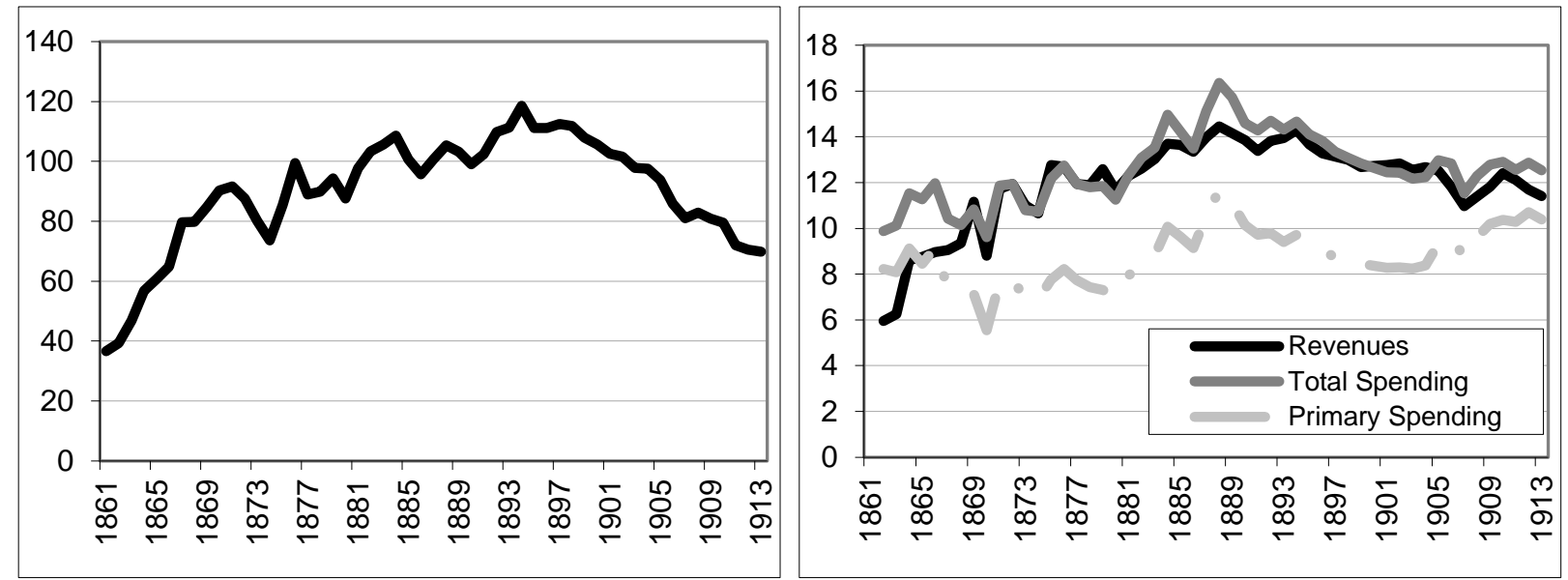

Source: data taken from Francese and Pace (2008), Baffigi (2011), RGS (2011).

The tax burden rose dramatically: from 6\% in 1862 to $13 \%$ in 1875 whereas spending was not sacrificed. To reduce the impact of fiscal tightening on the economy, the government opted for an accommodative monetary policy. Between 1866 and 1876 the money supply increased by more than two thirds. Over the same period, bank deposits increased fivefold (De Cecco, 2003). The balanced budget was reached in 1876, 
but the effort of fiscal consolidation led the Right-wing to defeat and put the Left-wing of Agostino Depretis in office.

\section{From the Left-wing to the Giolitti period}

During the Left-wing government, there was a huge growth in national imbalances, with a steady upward pattern in the debt-to-GDP ratio. The average public debt/GDP ratio rose to 103\% between 1876-1899, compared to $73 \%$ recorded in the previous phase (see Figure 2). The Italian economy was experiencing slow economic growth and price deflation: the inflation index was on average zero $(-0.04 \%)$, collapsing to $-6.7 \%$ in 1892. Other factors, such as the elimination of the corso forzoso (1883), the nationalization of the railways, the massive investment in railway construction and an equally large increase in public works, contributed to exacerbate the public imbalance. Public expenses and public debt grew especially during the Crispi government (1888-96) because of very costly military expeditions to Africa. The imbalance was particularly severe in 1888-89, when military expenses accounted for about $32 \%$ of total expenditure. The international crisis of 1893 had serious repercussions on Italian finances. The increase in national indebtedness, along with the financial crisis and banking system scandals, called for a major reform: with the banking act of 1894 the Banca Nazionale, Banca Nazionale Toscana and Banca Toscana di Credito merged to form the Bank of Italy. ${ }^{13}$ The new banking act established that only the Bank of Italy, Banco di Napoli and Banco di Sicilia had the right to issue currency. Another important measure to tackle the financial crisis was the end of convertibility of the lira in 1894. In this period of strong turbulence for the financial system, 1894 also represents the maximum level of debt-to-GDP ratio, amounting to $118.5 \%$, after which there started a phase of debt reduction that would last throughout the Giolitti period (Figure 2).

After the crisis of the 1890s, several governments succeeded one another until the First World War. One such government was that of Giovanni Giolitti, who opened a period known as the Giolitti era: a phase of expansion for the Italian economy, with significant growth in the industrial sector. During this period, many of the main Italian industrial companies were founded and the so-called industrial triangle Milan-TurinGenoa took shape. The real GDP growth rate rose, on average, to $2.6 \%$, while inflation was below $2 \%$; the burden of interest spending was lower than the previous period and primary expenses of the State budget surpassed revenues (see Figure 2). All these factors led, in the period 1900-1913, to a reduction in the average public debt/GDP ratio to $87 \%$, about 15 percentage points lower compared to the previous period 
(1876-1899). To better appreciate the contribution originating from economic growth, we can write the government budget constraint as a proportion of GDP:

$$
\frac{B_{t}}{Y_{t}}=\frac{B_{t-1}}{Y_{t-1}(1+g)}+\frac{i B_{t-1}+D_{t}^{p}}{Y_{t}},
$$

where $g$ stands for the nominal growth rate, $B_{t}$ and $D^{p}{ }_{t}$ are, respectively, the level of public debt and primary deficit, both expressed as a share of GDP, $Y_{t}$. By reformulating Equation (1) to highlight the dynamic of the debt-to-GDP ratio we get:

$$
\frac{B_{t}}{Y_{t}}-\frac{B_{t-1}}{Y_{t-1}}=\frac{B_{t-1}}{Y_{t-1}} \frac{-g}{(1+g)}+\frac{D_{t}^{t o t}}{Y_{t}}
$$

The first term on the right-hand side of Equation (2) shows that the evolution of the debt ratio can differ from the total deficit, $D^{\text {tot }}$, by a component which is a negative function of the nominal growth rate of the economy, opportunely weighted by the debt ratio (dividend growth). During the period 1900-1913, when the debt ratio fell from $105 \%$ to about $70 \%$ of GDP, the contribution of the growth dividend was negative, amounting, on average, to $-3.6 \%$ per year, compared to a positive contribution by total deficit, to be exact $+0.4 \%$.

The Giolitti era represents one of the few in which monetary and fiscal policy interacted positively, playing an important role in balancing the national budget and in curbing public debt dynamics (Paolo Panteghini and Franco Spinelli, 2002). The improved social conditions, and economic policies tailored to respond to development needs, allowed Italy to take advantage of a positive international economic situation. The reduction in military expenditure allowed the State to invest more in other items, such as heavy industry and public works.

One of the measures that contributed to the success of Giolitti’s policy was the so-called "rent conversion”, i.e. consolidation of the debt formerly issued at high interest rates in new bonds issued with a lower rate of 
interest. Following the example provided by the major European countries, this important financial measure was adopted in 1906 and contributed to shrink the burden of interest spending during the Giolitti period. ${ }^{14}$ This structural innovation in the management of public debt, along with the growth dividend effect, motivated a contraction in the debt-to-GDP ratio, which fell in 1913 to $70 \%$, a remarkable reduction of more than 30 percentage points in less than a decade.

\section{The period of the two World Wars: 1914-1945}

During the period 1914-1945, the two World Wars had considerable consequences on the public debt and primary deficit to GDP, which reached, together with the inflation rate, the highest levels of the whole sample analysed (1861-2010). From 1914 to 1945 the average growth rate of real GDP was negative, inflation ran on average at about $18 \%$ while the ratio of debt to GDP was $105 \%$. However, the dynamics of the economic variables were very different during the First World War, the Fascist period and the Second World War. Although the two sub-periods of the World Wars both experienced a severe slowdown in real growth and mainly monetary inflation, they differ in the magnitude of some processes. In particular, money supply and prices grew more in the second conflict compared to the first one.

\section{The First World War}

The First World War led to the collapse of the gold standard and a severe economic and financial crisis in all countries. In Italy, during the period 1914-21, the average ratio of public debt to GDP rose to about $112 \%$, reaching a maximum of $158 \%$ in 1920 . The average inflation rate was about $23 \%$, with a spike of $43 \%$ between 1917-18, while real GDP decreased on average by 1\% (see Table 1 and Figure 3).

Figure 3: public debt (left) and final revenues and outlays (right), proportion of GDP, 1914-1945 (percentage)

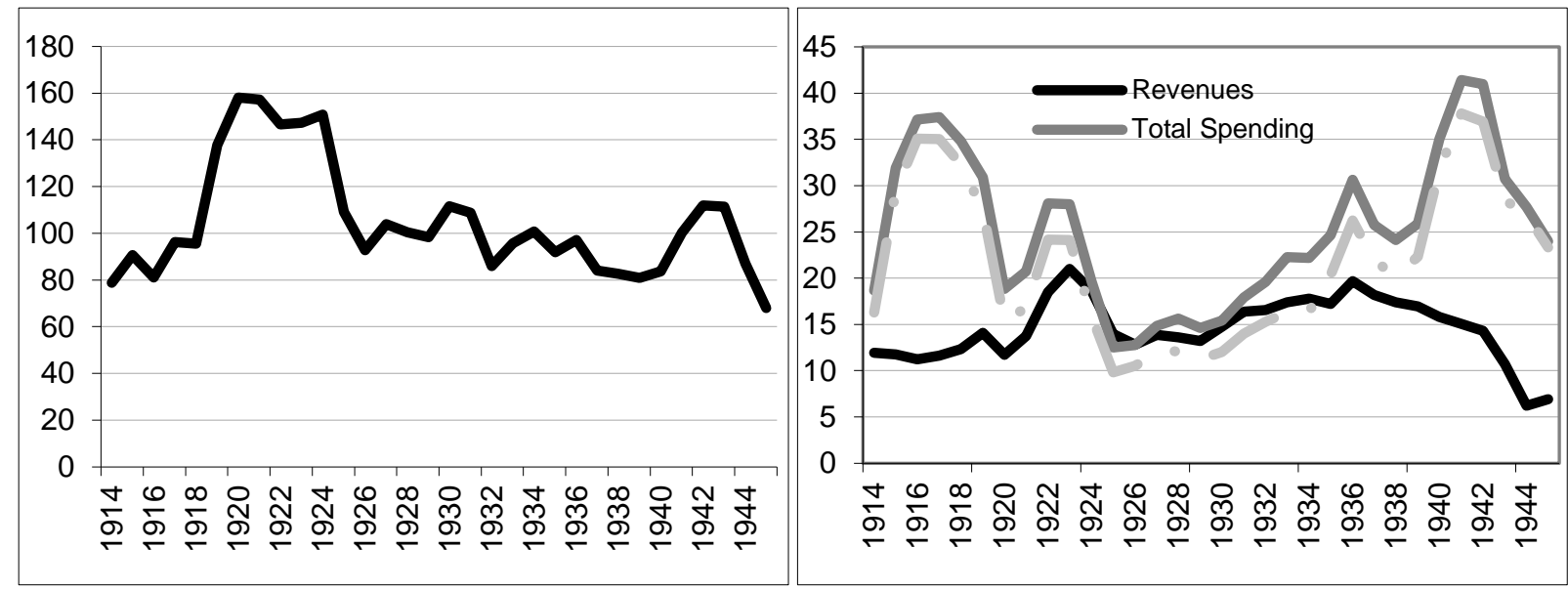


Source: data from Francese and Pace (2008), Baffigi (2011), RGS (2011).

The declaration of war by Austria against Serbia (July 1914) opened up a severe banking crisis; in order to curb the banking panic, in August 1914 a moratorium allowed the banks to limit reimbursement of deposits to $5 \%$ of the total amount. ${ }^{15}$ As well as in other European countries, the Bank of Italy suspended the gold convertibility of the lira, and the official discount rate increased up to $6 \%$ (Gianni Toniolo, 2003).

Preparation for the war effort and in particular the strengthening of the army and navy led to a significant increase in defence spending, which added to the cost of maintaining troops in Libya.

The higher costs were financed almost entirely by debt (internal and external) and money emission. During the period 1914-1919 the government authorized six national loans, to be precise in December 1914, June and December 1915, January and December 1917, November 1919. The increasing difficulties encountered placing the securities are evident from the fact that the market prices of the debt instruments decreased from 97 in December 1914 to 87.5 in November 1919, providing a strong increase in the yields. Moreover, not all the capital subscribed corresponded to new cash being raised, since much of it was a consolidation of previously issued bonds or national loans. ${ }^{16}$

In the years 1915-16 there was an exceptional increase in GDP and a consequent reduction of debt/GDP from about $91 \%$ in 1915 to $81 \%$ in 1916 . However, in the following two years, industrial production declined significantly while defence expenditures continued to grow during the same period. Considerable concerns were raised over foreign supplies of foodstuffs, raw materials and manufactured goods, and hence over the rapid growth of the trade deficit. As a consequence, the ratio of debt to GDP rose sharply to $96 \%$ in 1917. Therefore the most delicate problems rested on external indebtedness, because the lira had been devalued almost constantly in all markets, with some episodes of veritable currency crisis (OctoberDecember 1916, February 1917, June-July 1917, October 1917-March June 1918) (Toniolo, 2003).

After the armistice was signed (November 4, 1918), Italy had to face the economic and financial problems caused by the war. One of the most urgent problems was that of foreign loans granted by the Allies, without which Italy was unable to import commodities. In late 1918, the internal public debt had tripled compared to the levels reached before the First World War. The debt with the Allies grew even more rapidly. In the first post-war period the renewed strong depreciation of the lira multiplied the weight of foreign debt expressed in liras which reached that of the internal debt (Franco Cotula and Luigi Spaventa 2003). 
The paper money in circulation was quadrupled. The inflation rate was very high and exceeded that of the allied countries. The depreciation of the lira was more serious and costly for Italy because of the need to import raw materials and foodstuffs, and due to the weakness of the industrial and financial structure. In the first postwar period, social tensions were particularly acute. Unemployment was high and, due to high inflation, real wages and real interest rates were lower than in 1914. To recover the loss of purchasing power, nominal wages were greatly increased, especially in 1920, and this contributed to increase the inflationary process.

Exports significantly decreased and serious problems arose in financing imports of food, coal and raw materials. The end of British and American loans (Pier Francesco Asso, 1993) and the abolition of the monopoly of foreign exchange in $1919^{17}$ produced a sharp fall in the value of the lira against the US dollar and GB pound, and forced the Italian Treasury to increase the debt towards the issuing banks, causing a strong increase in money circulation. The net outflow of capital accentuated the depreciation of the lira, which interacted with inflation, in a dangerous vicious circle. Between November 1919 and April 1920, the lira devalued against the dollar by $92.9 \%$ and $85.3 \%$ against the pound (Cotula and Spaventa, 2003), and the ratio of public debt to GDP peaked at 158\% in 1920-21 (see Figure 3). The tax revenues could only cover about a third of government spending, driving high deficits to fuel inflation with additional monetary base. Between late 1919 and early 1920 the sixth national loan was issued.

\section{Fascist Italy and the Second World War}

The Fascist rise to power took place in October 1922, under critical social and political conditions. Between 1922 and 1938 GDP increased, on average, by $2.8 \%$ per year, while per capita growth was $1.9 \%$ a year. It is useful to identify four different subperiods in the Fascist era with reference to the financial and economic variables. In 1922-1926, the average annual growth of GDP was rapid: $5.6 \%$ in total terms and 4.62 in per capita terms. The subsequent years, 1927-1934, experienced stagnation: the annual total GDP increased by 0.6 percent while per capita GDP decreased (-0.27). The structure of the economy was affected by the 1929 global crisis to the same extent as in other Western European countries, although much less than the limiting cases represented by Germany and the United States. Two significant recessions occurred in 1930 (-4.7) and 1936 (-3.5). There was rapid economic expansion in the period 1935-38, with an average GDP growth of about $4 \%$ (2.8\% in per capita terms). 
Between 1922 and 1938 the public debt-to-GDP ratio was on average about $107 \%$ but in 1922, when Benito Mussolini was appointed Prime Minister, the public debt to GDP ratio was about $147 \%$ and two years later rose to $151 \%$. The problem of debt at the end of the First World War was not only a question of size, but also composition. Almost half of the debt was short-term . During the first phase of Fascism (1922-1926), Alberto De Stefani (the Minister of Finance) was able to significantly reduce government expenditure and increase tax revenues. ${ }^{18}$ However, the reduction in the debt/GDP ratio, from $151 \%$ in 1924 to 93\% in 1926, was mainly achieved by robust GDP growth (on average $5.6 \%$ between 1922 and 1926) and a strong recovery in inflation (on average $3.7 \%$ between 1922 and 1926 with a peak of 16\% in 1925). In 1926 the objective of a balanced budget was achieved. In addition, between 1925 and 1926 the amount of foreign debt diminished considerably thanks to the signing of treaties, with a significant reduction of war debts towards the United States and Great Britain. ${ }^{19}$ Starting from July 1926, funding problems emerged to renew the stock of floating debt. The new Finance Minister, Giuseppe Volpi, who believed that the continuous renewal of short-term debt, the amount of which was considerable, constituted a threat to the stability of the exchange rate, decided on a forced consolidation of debt. All government bonds with a maturity shorter than seven years were mandatorily converted into nine-year bonds, with an interest rate of $5 \%$ (the so-called Littorio loan). ${ }^{20}$ In 1927 Italy returned to the gold standard, with a revaluation of the lira usually referred to as "quota 90 " because the exchange rate was set at 90 lire to the pound. ${ }^{21}$ Restrictive monetary policies slowed GDP growth and lead to deflation, causing a resurgence of the debt-to-GDP ratio, peaking to $104 \%$ in 1927 . After that, the robust growth of GDP experienced in 1928-29 allowed the debt ratio to decline to $98 \%$ in 1929 , despite State budget imbalances. The effects of the Great Depression, with a deep financial and economic recession affecting the Italian economy until 1935, caused a sharp rise in the debt ratio to about $112 \%$ in 1930. To cope with the crisis of the industrial and banking system in Italy, the IRI was created in 1933, and in 1936 the new banking act put an end to the banca mista system in Italy. ${ }^{22}$

The economic situation changed radically in 1935, when the government took measures to finance the colonization of Ethiopia. The increase in public spending and arms production drove the recovery of the Italian economy. In 1936, the lira was devalued and military spending was financed largely with money issue. The annual inflation rate increased rapidly, which made it possible to accumulate budget deficits to 
finance the African colonies while achieving a reduction in the debt/GDP ratio, from 92\% in 1935 to $83 \%$ in 1938.

During World War II, there was a sharp reduction in per capita GDP. Total expenses of the State budget more than doubled between 1938 and 1942 and military expenses represented more than $50 \%$ of primary spending, reaching a peak of 63\% in 1942. The period from 1943-44 to 1946-47 was characterized by the occupation of Italy by German and Anglo-American forces. ${ }^{23}$ As a consequence, there was a split in the financial management, and the issuing of AM-lire by allied forces contributed to the inflationary process (Michele Fratianni and Franco Spinelli, 2001). ${ }^{24}$ Despite the huge budget deficit, between 1943 and 1947, hyperinflation, which soared to $143 \%$ in 1944, allowed a far higher nominal income growth than that of debt, with a drastic reduction in the debt/GDP ratio, amounting in 1945 to 68\%. Hyperinflation wiped out the debt service which had so heavily influenced the previous periods.

\section{Debt stabilization during the economic boom: 1946-1970}

The second post-war experienced stabilization of the ratio of public debt to GDP, which oscillated about 31\%, with a low variance during the whole period (Table 1 and Figure 4). In particular, we can distinguish the reconstruction in the years immediately following the end of the war (1946-50) and the long period of economic boom with moderate inflation (1950-70).

The reconstruction period and the role of inflation

Nearly five years of war had caused serious structural damage to the transport system, public works, equipment and buildings, and electricity networks. In 1945 the national income, at constant prices, decreased by $40 \%$ compared to 1938 , industrial value added fell to less than a third and consumption declined by about $40 \%$. The situation was aggravated by a large balance of payments deficit, with gold reserves which were virtually zero, in part due to requisition by the Nazis. The most urgent problem was to provide for the basic needs of the population. It was absolutely necessary to recover production and resume imports of foodstuffs, raw materials and coal.

Italy had emerged from World War II defeated but it could nevertheless count on the support of the allies, mostly American, to overcome the economic difficulties and ensure the survival of the population. To 
facilitate the recovery of the European economies, the US launched the Marshall Plan, a comprehensive program of economic assistance. ${ }^{25}$

In 1945, when the debt-to-GDP ratio was $68 \%$, the ratio of expenditures to GDP amounted to $24 \%$ while revenues were about $7 \%$ and the ratio of total deficit to GDP had increased from $6.8 \%$ in 1938 to $17 \%$ by the end of the war (Figure 4).

Figure 4: public debt (left) and final revenues and outlays (right), proportion of GDP, 1946-1970 (percentage)
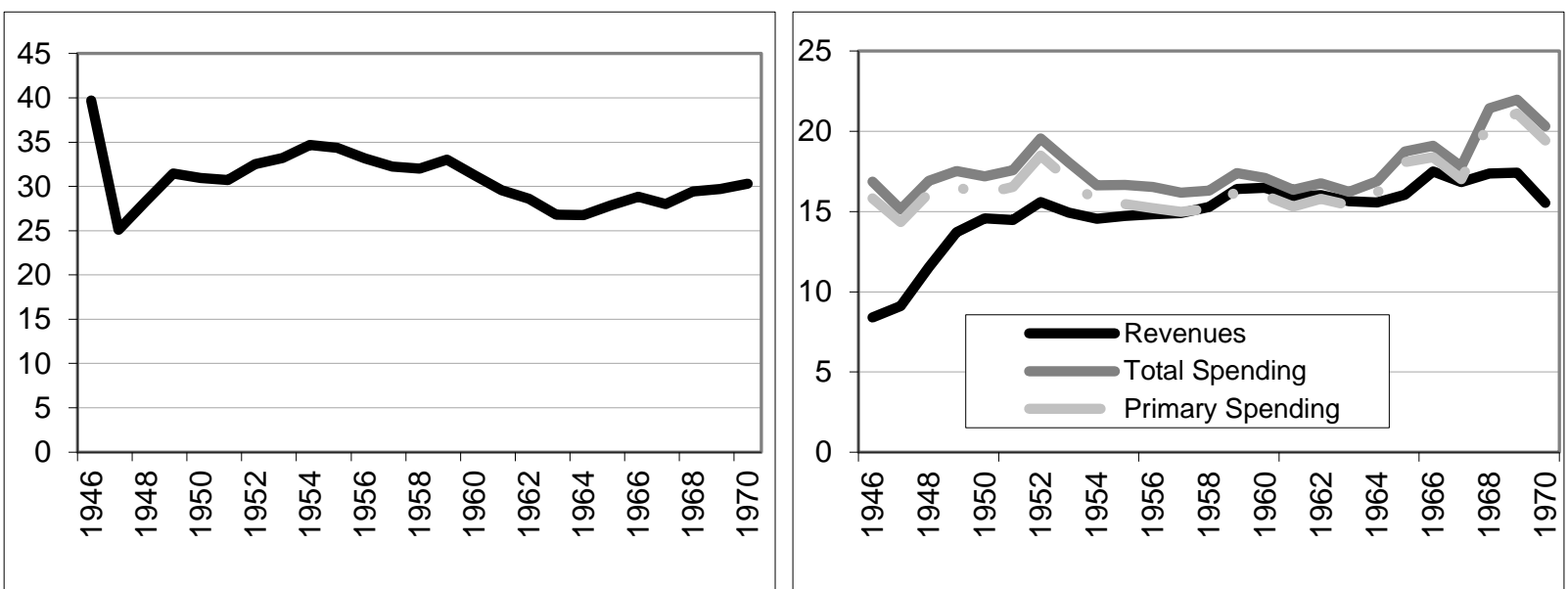

Source: data from Francese and Pace (2008), Baffigi (2011), RGS (2011).

The debt structure had changed during the Second World War, with a larger short-term component. Moreover, it was common practice to require the Central Bank to finance part of the debt, so that inflation grew enormously leading to a drastic reduction in the debt-GDP ratio. After the peak of $143 \%$ in 1944, inflation lowered to 107\% in 1945 and in 1946 it was still 66\%, with the debt ratio decreasing from 88 to 68 and finally 40\% in 1946. In 1947, the debt/GDP ratio, resulting from high inflation, reached its lowest record, amounting to $25 \%$. At the end of World War II the solution to the problem of public debt may be said to have been achieved by inflation tax. However, hyperinflation and the sharp devaluation of the lira were not compatible with the system of fixed exchange rates established by the Bretton Woods Agreement of 1944. The expansion of bank credit did not have adequate institutional limits to curb the effect of multiplying the money supply. In this context Einaudi and Menichella, respectively Governor and general manager of the Bank of Italy, carried out a monetary stabilization maneuver in 1947, which was essentially based on the objective of reducing the expansive inflationary role of the bank credit multiplier. To achieve the goal, the official rate of discount was increased and a system of compulsory reserves was introduced, i.e. banks had to 
lodge a share of their deposits with the Bank of Italy. The Einaudi credit crunch had a strong disinflationary effect, with the inflation rate falling to 9.3\% in 1948 and becoming even negative (-2.7\%) in 1949, allowing Italy to join the International Monetary Fund. The real growth rate had fallen from 19\% in 1947 to about 8\% in the period 1948-1950, but the Italian industrial structure was still lagging behind the major industrialized countries. ${ }^{26}$

\section{The economic boom}

The new Italian Republic was born in 1946 with a public debt of about 40 \% of GDP, slightly higher than the level of the new Kingdom of Italy in 1861, when it amounted to 37\%. The massive demand to finance reconstruction, and the need to convert and develop industries required a large savings formation to avoid increasing the current account deficit with foreign countries. The per capita income of the Italians was still very low in absolute terms and in comparison to the more advanced Western economies. At the end of the war, Italy was still an essentially agricultural country. About half of the population was employed in the agricultural sector which provided more than a quarter of the value added. The North-South gap was much wider than today. By 1950 the per capita income had caught up with 1938 levels but still amounted to only half the English per capita income levels and about 2/3 of those in France (Angus Maddison, 1995). The propensity to save was aided by monetary policy and banking policy implemented by Menichella, designed to defend monetary savings from inflation and preserve the stability of credit institutions. Such policies stimulated the demand for government bonds, also thanks to the structure of interest rates. The sharp decline in public debt relative to GDP, achieved in the late 1940s thanks to inflation, allowed a margin for increasing public spending, although Einaudi supported the need for State indebtedness not to grow excessively. They gave full support to the "Vanoni plan", a scheme to develop employment and income in Italy during the decade 1955-64, aiming to spur production and absorb unemployment. From 1951 to 1968, the Italian economy underwent major transformations. This period witnessed exceptional economic growth and the strong growth of industrial production. During the Fascist period, industry’s value added had exceeded that of agriculture, but it was during the Italian "economic miracle” (1953-1968) that the number of workers in industry exceeded those working in agriculture.

In the period 1950-61, industrial value added increased at an average annual rate of 9\%, average investment by about $13 \%$. The rapid productivity growth strengthened competitiveness, leading to trade expansion with 
foreign countries. The strong GDP growth led to a further reduction in the ratio of public debt to GDP, form $31 \%$ in 1950 to $27 \%$ in 1963.

In the 1950s, the objective of expanding trade with foreign countries was achieved together with the objectives of sustained growth in income and investment and monetary stability. In the second half of the same decade the external convertibility of the lira was restored after the balance of payments had achieved a strong position and restrictions on capital movements were eased. The balance of payments and the availability of reserves were no longer an obstacle to the possibility of improvements in infrastructure and industrial facilities and the reduction of unemployment.

\section{Fiscal indiscipline: 1970-2010}

The peak in public debt recorded nowadays is the consequence of an almost uninterrupted rise beginning in the early 1970s, with fiscal consolidation starting only in the mid 1990s. A succession of primary deficits lay at the origin of debt growth, but several aspects, such as the effects of the real interest cost of debt and of the GDP growth rate, have affected the debt dynamics.

The 1970s: debt is inflated away

In the 1970s major changes occurred with respect to the post-war period, not only in the Italian productive structure and its ability to increase employment, but also in the average returns of financial assets. This change was mainly due to the acceleration of the inflationary process heavily fuelled by the oil shocks. The early 1970s marked an important turning point for the Italian economy. The ultimate failure of the system of Bretton Woods, occurring in the early months of 1973, and the energy crisis in the autumn of that year exacerbated the already high inflation rate and the imbalance in external accounts. The change in the terms of trade imposed a real burden on the economy, which suffered a balance of payments crisis and produced a situation of stagflation. The balance of payments was also supported by measures to control currency movements and with a massive use of international loans. Those of the IMF in 1974 committed Italy to a severe deflationary policy. In addition, for the first time, there was a sharp drop in the growth of sectors related to the use of petroleum products. Thereafter, until the end of 1975, the most severe postwar crisis occurred. The period was also characterized by a high rate of devaluation of the lira. In 1974 and 1976, within a few weeks, the effective exchange rate of the lira lost about 7 and $18 \%$ respectively, creating the 
conditions for an increase in exports and changes in relative prices, with an increase of profits that contributed to the recovery of' economy, once again halted by a second oil shock. ${ }^{27}$

Figure 5: public debt (left) and final revenues and outlays (right), proportion of GDP, 1971-2010 (percentage)
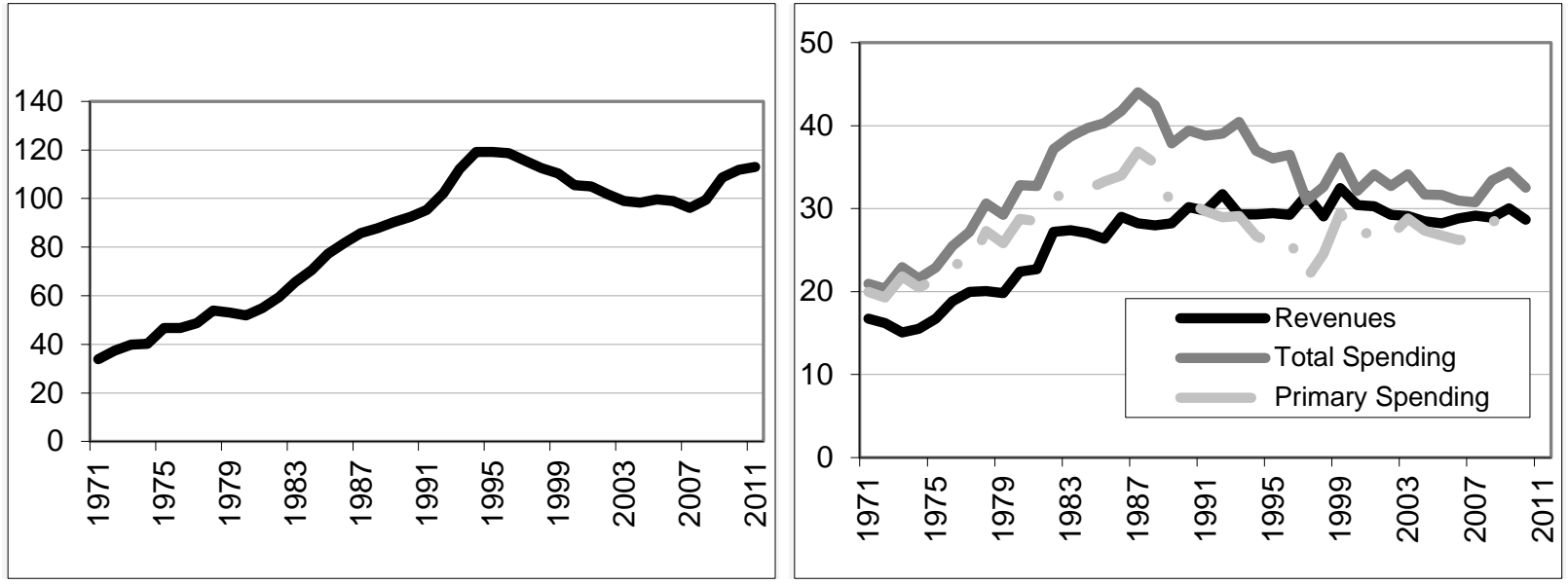

Source: data from Francese and Pace (2011), Baffigi (2011), RGS (2011).

The price dynamics generated negative real returns and had a strong impact on the dynamics of public debt. ${ }^{28}$ These circumstances were made possible by a strong monetary base creation through the channel of the Treasury. Until the mid-1970s, this component amounted to about $80 \%$ of the State sector borrowing requirement. Only in 1977 was this source of funding cut off but, in the late 1970s, it still reached 30\% of State requirements.

According to Rainer Masera (1979), the price dynamic in the 1950s and '60s was marked by substantial stability: the average annual rate of inflation (using the GNP deflator) was 4.1\% in the period 1949-1960 and 4.5\% in the period 1960-70. Under these conditions, it was reasonable to assume that cumulative experiences conferred a high level of stability to the system. This allowed a medium-long term expected rate of increase in prices to be formulated between 4 and 5\% which could be regarded as the "national tendency" to inflation. The advantage of this situation was precisely to allow the financial markets to rely on a "defined" interest rate (as a normal threshold). Indeed, future expectations on inflation (even in the long run) could be reliably based on the set of information contained in past history. This is a prerequisite to attract capital and grow. The experience of the 1970s is sharply different. The dynamic of prices, at the beginning of the decade, showed changes of about $7 \%$ and rose to $18 \%$ in $1974-77$. The explosion of the inflationary process may well have destroyed the confidence in the experience acquired in the 1950s and '60s. The creation of a 
monetary base through the Treasury generated a weakening of the currency and the high inflationary pressures, especially after the drop in the external value of the lira in 1974 and 1976.

Obviously, in those years, long-term securities were secured only through administrative measures (pushing banks to hold securities in their portfolios), as "free" investors virtually abandoned the market. As a consequence, Italy approached the 1980s with a short and rapidly declining maturity of public debt. In 1981, about $60 \%$ of the debt had a maturity of less than a year, a figure certainly dangerous for the years to come. As pointed out by numerous studies of the time, there exists a close and positive relationship between short and concentrated maturities and crises of confidence. ${ }^{29}$

\section{The 1980s: The worsening of the fiscal imbalance}

From the second oil shock to the late 1980s, the Italian public deficit hovered around $10 \%$ of GDP. No other Western country reported similar results. ${ }^{30}$ As shown in Figure 5, public debt grew very rapidly (debt explosion) until its stabilization in the mid of the 1990s. This was due, in large part, to an important innovation in the conduct of monetary policy: from 1950 to the 1970s, a large part of public debt was financed by an expansion of the monetary base; by contrast, starting from 1981, with the "divorce" between the Bank of Italy and the Italian Treasury, the contribution of the monetary authorities to the funding of fiscal policy considerably reduced. ${ }^{31}$ Financing deficits with the placement of securities on the market led to a growing weight of government securities in the portfolio of the private sector, requiring a risk premium for their placement and giving a boost to the whole structure of interest rates. Unlike the 1970s, when real interest rates were largely negative, there were positive real interest rates for the whole period 1980-1992, with short-term rates averaging $4 \%$ and long-term $4.2 \%{ }^{32}$

Public expenditure policy underwent a significant change, facing strong demand for social spending and the construction of a Welfare State which had already been developed by other Western countries. Moreover, social and economic demands from the late 1970s onwards and tensions on the labor market gave rise to a series of redistributive policies with the launch of huge transfers to households, and disbursements of free services. The institutional characteristics of the Italian labor market and its segmentation in terms of age, gender, skill and regions, along with the lack of flexibility and the rise in wages, led the unemployment rate to increase continuously, rising from $7 \%$, to $12 \%$. At the same time, a series of long-term plans were carried out for public investment and an increase in the number of public employees, while bureaucracies were 
developed extensively throughout the country and in all public services. This strong growth in public spending occurred in the presence of an inadequate tax system which was unable to follow the changes in income flows. $^{33}$

The other factor that drove public expenditure in the 1980s was the increase in prices of raw materials and oil at the beginning and end of the 1970s. In this context, fiscal policy became expansionary, maintaining a GDP growth rate in line with the European average, but fuelling inflation. All this led to a sustained imbalance of public accounts and took over 10 years the debt/GDP ratio from 40\% in 1973 to over $60 \%$ in 1983.

A further key element of this fiscal imbalance is that fiscal policy decisions were far from being taken by rational players. Fiscal deficits were the outcome of a great many short-sighted decisions, taken during a redistributive struggle between many players. The policy equilibrium set up in those decades was framed by extremely fragile political coalitions, sensitive to any change such as a monetary regime change, a domestic or international shock or changes in policy or/and economic preferences. ${ }^{34}$ As Nouriel Roubini and Jeffrey Sachs (1989), Alberto Alesina and Roberto Perotti (1995) and many others have stressed, the political fragmentation, the income inequality and other sources of heterogeneity produce fiscal disequilibrium. Government spending in the 1980s grew in an uncontrolled manner because the present and future associated burden was systematically underestimated by the decision-making process.

Pressure to reduce deficits in Italy was in fact lower than in several other countries during the 1980s. This was also due to the presence of large household savings that allowed easy financing of the deficit. In addition, in Italy, from the 1980s onwards, the presence of a significant informal sector and hence serious tax evasion are statistically proven (Raffaella Basile et al. 2011). This is an important factor in the formation of the deficit and also helped to generate higher rate of savings with which to finance the deficits. Finally, the economic crisis and social conflicts required government intervention to support the production system and redistribution.

\section{EMU as a discipline device}

In the early 1990s, after the currency and financial crisis of 1992 and the disintegration of the European Monetary System, there began an important process of adjustment of the public finance disequilibrium. The decade started with the government's dramatic financial position, with a public deficit of about 9-10\% of GDP and a public debt exceeding 90\% of GDP. Moreover, Italy suffered from an equally dramatic political 
crisis. In these circumstances, Giuliano Amato (a socialist Prime Minister) undertook a "healing process" of public finance.

The financial act of 1992 was a fiscal contraction amounting to 6\% of GDP, and helped avoid the bail-out of public debt (see Figure 5). The restoring of the public finance equilibrium was pursued through major cuts to public spending, with some structural reforms, such as privatization and the end of the system of Partecipazioni Statali and the reform of the social security system. ${ }^{35}$ In particular, in 1992, expenditure on public pensions had reached almost 13\% of GDP with some dramatic and unsustainable projections for the next decades. The Amato reform first, and later on, in 1995, the crucial reform of Lamberto Dini who steered a pension system mostly based on a pay-as-you-go scheme towards a contribution-based system, contributed to bring pension spending under control.

The process was also accompanied by stronger fiscal pressure, with a sharp rise in the tax rate with a peak reached in 1997, mainly due to extraordinary revenues connected to the so-called "tax for Europe”, raised by the government to comply with the requirement to join the European Monetary Union (1997). Finally, a process of lengthening of the debt maturity structure and declining interest rates led to a sharp decline in the average cost of debt (the ratio of interest payments to overall debt) from 1993.

At the beginning of 1990s, joining the Economic and Monetary Union was agreed with the aim of setting a proper balance between fiscal discipline and the macroeconomic stabilization role of fiscal policy. It was for Italy a "discipline device” which was to ensure budgetary balances close to balance or in surplus, while keeping or even reducing gross debt levels in terms of GDP. Many authors claimed that EMU would actually reduce the occurrence of country-specific shocks, also because it would limit the possibility of policyinduced shocks. EMU fiscal rules would limit the scope for major fiscal slippages by national governments. ${ }^{36}$

In the past 15 years, the conduct of the fiscal policy and the pattern of the public debt has been strongly affected by the budgetary rules imposed by the Stability and Growth Pact. However, Italian governments face growing demands to increase public expenditures and fulfil promises of retirement and health care benefits to retirees, whereas growth in the workforce and production of goods and services have slowed and the population has aged rapidly. The EMU, with the Maastricht treaty parameters, has placed huge conflicting pressures on the Italian national budget, pointing toward growing debt levels: a very modest 
economic growth (almost zero in several years, 11\% from 1995 to 2009) did not allow an improvement in the financial imbalance that stayed close to $110 \%$ of GDP during the decade 1996-2005. During the period 1995-2010, the average contribution of the growth dividend to the dynamic of the debt to GDP ratio (defined in Equation 1), was negative, $-3.8 \%$, but the positive contribution of the total deficit (which amounted to $+3.6 \%$ ) choked off the growth effect on the dynamic of the debt/GDP ratio (on average $-0.7 \%$ ). The most important component of the growth dividend was inflation, around $3 \%$, while the growth in real terms did not reach $1 \%$. The budget rules imposed by the Monetary Union have been successful in attaining fiscal discipline (on average, total deficit decreased from 12\% of GDP in the decade 1980-1990, to 3.3\% in the period 2000-2010) but they have severely restricted the growth of the economy.

Comparing these figures with those obtained during the period 1894-1912, we can explain the striking reduction of a similarly high level of debt: the dividend growth was, on average, $-3.2 \%$, decomposed by an average inflation amounting to $1.6 \%$ and a growth of the real economy by $2 \%$. Most importantly, during this period, the contribution of the deficit was negligible, $+0.3 \%$, which allowed the debt ratio to be reduced by on average $2.1 \%$ per year.

\section{Is the Italian public debt sustainable? An answer based on the fiscal rule}

From the above description of the complex succession of events that have occurred over the long time span of the Italian State, it clearly emerges that coping with budget imbalances has been a feature common to the entire life of the Italian State. However, a very variegated pattern for public debt over the observed sample has emerged from the reading of the previous sections. Here we try to place the evidence of facts described above within a unitary statistical-framework, to ascertain whether there has been a common strategy, perhaps not always conscious, by Italian fiscal authorities, aiming to run a sustainable fiscal policy.

The time series approach to sustainability

In the time series approach to sustainability, a number of stationarity and cointegration tests are recommended to verify whether the Present Value Budget Constraint (PVBC) holds:

$$
B_{t}=\sum_{j=0}^{\infty} \frac{-D^{P}{ }_{t+j}}{(1+i)^{t+j}} \quad \text {; }
$$


where $D^{P}$ stands for the net-of-interest deficit, and $i$ is the appropriate interest rate. ${ }^{37}$

However, the PVBC is not unanimously accepted as a signal of fiscal solvency. An alternative view is the so-called indicator approach, which pays less attention to the PVBC, focusing instead on indicators of sustainability that are not grounded in theory (Olivier Blanchard et al. 1990; Nigel Chalk and Richard Hemming, 2000).

Within the time series approach, Trehan and Walsh $(1988,1991)$ demonstrate that if public debt is difference stationary, a simple test of intertemporal budget balance reduces to a check for the stationarity of the deficit inclusive-of-interest. According to Trehan and Walsh (1988), this condition is necessary and sufficient under the assumption that the expected value of the real interest rate, $r$, be constant. In this case the debt and the net-of-interest deficit are of the same order of integration and cointegrated, with the cointegrating vector being $(1,-r)$, or, equivalently, that revenues, non-interest spending and debt are cointegrated with vector (1, $1,-r)$.

Moreover, Trehan and Walsh (1991) show that the test based on the stationarity of the deficit inclusive-ofinterest continues to be valid, i.e. it is a sufficient condition to ensure intertemporal budget balance, as long as the expected real rate of interest is allowed to vary but is strictly positive. This latter result is independent of any assumption about possible cointegration between the debt and the net-of-interest deficit. ${ }^{38}$ Bohn (2007) casts doubt on the necessity of stationarity and cointegration restrictions, claiming that the class of tests commonly used in literature are special cases of a more general sufficient condition for sustainability, i.e. that a debt series is integrated of any finite order $m \geq 0$. Bohn (2005) criticizes the definition of sustainability based on the PVBC ("ad hoc sustainability"), claiming that there is no "economic argument why potential buyers of government bond should care” about it. Alternatively, the author recommends adopting a "model-based” approach to sustainability, suggesting that sustainability can be tested by estimating an appropriate policy rule, i.e. a reaction function for the primary surplus to the debt-GDP ratio. ${ }^{39}$ This very intuitive representation of debt sustainability refers to a relationship between public debt and primary surplus: when the debt rises, a sustainable fiscal policy requires an increase in primary surplus. Estimates of the fiscal rule for Italy 
Here we follow the approach recommended by Bohn (1998, 2005), but, consistently with Takero Doi et al. (2011), we allow for smoothed adjustment of primary surplus by including an AR(1) term in the estimated fiscal rule. By allowing the primary surplus to depend upon its past value, on the one hand we control for a possible deficit bias and, more generally, for a sluggish budget process; on the other, we estimate the coefficients of the fiscal rule limiting the statistical problems originating from autocorrelated residuals. ${ }^{40}$ Our dependent variable is the primary deficit-to-GDP ratio, $\frac{D_{t}^{P}}{Y_{t}}$, and we estimate the following government's reaction function:

$$
\frac{D_{t}^{P}}{Y_{t}}=c+\beta \frac{B_{t-1}}{Y_{t-1}}+\alpha_{1}(\text { GDPcycle })+\alpha_{2} \frac{\text { MilSpending }_{t}}{Y_{t}}+\rho \frac{D_{t-1}^{P}}{Y_{t-1}}+\varepsilon_{t}
$$

Given that the debt time series, which is collected on a monthly basis, has been annualized by taking the value recorded at the end of the calendar year, in order to respect the algebra of the budget constraint, the debt ratio is considered with one lag length in the policy reaction function estimated through the OLS regression, $\frac{B_{t-1}}{Y_{t-1}}$. Moreover, we control for the influence on the primary budget from explanatory variables accounting for temporary government spending, and a business cycle: respectively, the military component of public spending (MilSpending) and the Hodrick-Prescott cycle of real GDP (GDPcycle). Table 2 reports the estimation results of Equation 4 for each of the historical periods examined in previous sections. Sustainability requires that government reduces the primary deficit sufficiently in response to increasing government debt. Therefore we expect a negative sign for the $\beta$ coefficient (column 3 ), and a negative coefficient for the GDP cycle, since automatic stabilizers of the government budget reduce the primary deficit during economic booms whereas they increase it during downturns (column 4). Finally, as to military spending, it is a proxy for temporary government expenditure, which worsens the budget balance. Hence the $\alpha_{2}$ coefficient is expected to be positive (column 5). ${ }^{41}$

Table 2: estimated coefficients of the fiscal rule, dependent variable primary deficit/GDP.

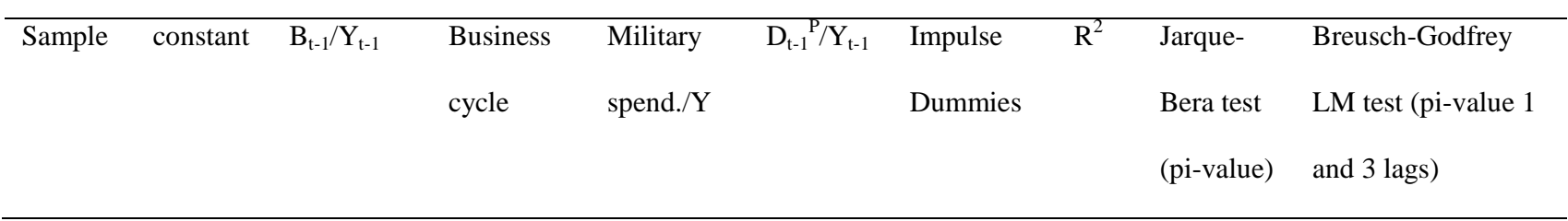




\begin{tabular}{|c|c|c|c|c|c|c|c|c|c|}
\hline 1862- & -0.22 & $-0.02 * * *$ & $0.077^{* *}$ & $0.31 * * *$ & $0.597 * * *$ & 1869,1875, & 0.94 & 0.61 & $0.93 ; 0.80$ \\
\hline 1913 & $(0.46)$ & $(0.007)$ & $(0.03)$ & $(0.12)$ & $(0.07)$ & 1906 & & & \\
\hline 1914- & -2.59 & -0.01 & $-0.15 * * *$ & $0.84^{* * *}$ & $0.23^{* *}$ & 1944 & 0.95 & 0.75 & $0.0005 ; 0.001$ \\
\hline 1945 & $(2.55)$ & $(0.02)$ & $(0.056)$ & $(0.11)$ & $(0.09)$ & & & & \\
\hline 1946- & $3.7 * * *$ & $-0.09 * *$ & 0.07 & -0.26 & $0.74 * * *$ & 1968 & 0.91 & 0.93 & $0.32 ; 0.005$ \\
\hline 1970 & $(1.21)$ & $(0.04)$ & $(0.05)$ & $(0.53)$ & $(0.06)$ & & & & \\
\hline 1971- & $7.4^{* * *}$ & $-0.057 * * *$ & -0.19 & -1.4 & $0.53 * * *$ & 1987, 1997 & 0.89 & 0.40 & $0.20 ; 0.47$ \\
\hline 2009 & $(2.56)$ & $(0.01)$ & $(0.15)$ & (1.3) & $(0.09)$ & & & & \\
\hline
\end{tabular}

The dependent variable is the primary deficit, in each cell the estimated OLS coefficients are shown, standard errors in parenthesis

$*, * *, * * *$ denote statistical significance, respectively, at 10, 5 and $1 \%$.

As expected, during the two World Wars, military spending was statistically significant and positively affected the primary deficit, with a particularly high coefficient. The estimated coefficient for the business cycle variable is significant, although positive, during the period 1862-1913, attesting to a pro-cyclical fiscal policy; conversely, it is significantly negative during the two World Wars. Interestingly, the business cycle variable, in the last two periods proves to be not statistically significant. Two distinct factors may drive these results. First, with regard to the 1946-70 period, the extraordinary growth of the economy has accompanied an equally extraordinary growth in public expenditure. For the last period (1971-2009), a stifled economic growth was unable to exert any effect on public finances.

The negative coefficients reported in the third column of Table 2 suggest that the debt dynamics was sustainable during the entire life of the Italian State, although the estimated $\beta$ coefficient is not significant during the period 1914-1945, when the fiscal stance and the debt dynamic were driven by war events. To check whether the response of fiscal policy to increasing debt was sufficient to guarantee sustainability we can follow the analysis by Doi et al. (2011), who obtain a sustainability condition involving the estimated parameters of the fiscal rule and the difference between the rate of interest and the rate of GDP growth. Starting from the debt accumulation dynamic: 
$\frac{B_{t}}{Y_{t}}=(1+i-g) \frac{B_{t-1}}{Y_{t-1}}+\frac{D^{P}}{Y_{t}}$

which states that as long as the primary budget is in balance, the debt grows at a rate given by the difference between the average interest rate on public debt, $i$, and rate of growth of GDP, $g$, if we substitute the fiscal rule of Equation (4), we obtain an $\operatorname{AR}(2)$ form for the debt process:

$\frac{B_{t}}{Y_{t}}=(1+i-g+\beta+\rho) \frac{B_{t-1}}{Y_{t-1}}-\rho(1+i-g) \frac{B_{t-2}}{Y_{t-2}}+\alpha_{1}(\text { GDPcycle })_{t}+\alpha_{2}\left(\frac{\text { MilitarySpending } t}{Y_{t}}\right)+\varepsilon_{t}$

After some manipulations, Equation (6) can be expressed as follows:

$\Delta \frac{B_{t}}{Y_{t}}=[(1-\rho)(i-g)+\beta] \frac{B_{t-1}}{Y_{t-1}}+\rho(1+i-g) \Delta \frac{B_{t-1}}{Y_{t-1}}+\alpha_{1}(\text { GDPcycle })_{t}+\alpha_{2}\left(\frac{\text { MilitarySpending }_{t}}{Y_{t}}\right)+\varepsilon_{t}$

This formulation for the debt process is interpreted by Doi et al. (2011) as the augmented Dickey Fueller test for the debt series. Hence, a possible condition for the stabilization of debt is to restrict it to a stationary process, by requiring the first coefficient of Equation (7) to be negative:

$[(1-\rho)(i-g)+\beta]<0,(8)$

which can be rewritten as follows:

$\frac{-\beta}{1-\rho}>(i-g)$

Equation (9) is the threshold condition that guarantees a sustainable fiscal policy; all the parameters are known: $i$ can be approximated by the ratio between interest spending and outstanding debt; $g$ is available in the data set; $\beta$ and $\rho$ are the estimated coefficients for Equation (4) listed in Table 2. The term on the right hand side of Equation (9) summarizes the dynamic of the debt-to-GDP ratio independent of the primary 
deficit, while the left hand side is the steady state level of primary surplus (both terms are expressed as a share of the debt-to-GDP ratio) under the fiscal rule stated by Equation (4). Actually, the latter is a first order difference equation; hence it can be solved for the steady state value of the primary deficit/surplus as follows:

$\frac{\widehat{D^{P}}}{Y}=\hat{c}+\beta \frac{\widehat{B}}{Y}+\rho \frac{\widehat{D^{P}}}{Y}$

and rearranging:

$\frac{\widehat{D^{P}}}{Y}=\frac{\hat{c}}{1-\rho}+\frac{\beta}{1-\rho} \frac{\widehat{B}}{Y}$

where the hat symbol indicates the steady state value of the variable of interest, while the term $c$ includes all the exogenous and constant parameters.

Equation (11) states that if a government follows a fiscal policy rule such as that expressed in Equation (4), then in steady state the primary deficit/surplus is a stable share, $\frac{\beta}{1-\rho}$, of the debt. Of course, sustainability requires that the $\beta$ coefficient is negative. Hence Equation (11) states that in steady state the fiscal rule implies a primary surplus.

The threshold condition of Equation (9) emphasizes that although a fiscal rule is implemented, it should be strong enough to guarantee that the automatic positive contribution to the debt dynamic, $(i-g)$, is more than offset by the negative contribution originating from the steady state primary surplus implemented under the fiscal rule, $\frac{\beta}{1-\rho}$.

In Table 3 we show, for each historical period examined in the previous sections, the average recorded values of the relevant parameters and the arithmetic of the sustainability condition expressed in Equation (9).

Table 3: the condition ensuring sustainability of the fiscal policy

\begin{tabular}{|c|c|c|c|c|c|}
\hline & & 1862-1913 & 1914-1945 & $1946-1970$ & 1971-2009 \\
\hline \multirow[t]{3}{*}{$\mathrm{r}$} & & 0.042 & 0.033 & 0.031 & 0.068 \\
\hline & $\bar{g}$ & 0.016 & -0.003 & 0.082 & 0.02 \\
\hline & $r-\bar{g}$ & 0.026 & 0.0357 & -0.05 & 0.049 \\
\hline
\end{tabular}




\begin{tabular}{lllll}
\hline & $\mathbf{1 8 6 2 - 1 9 1 3}$ & $\mathbf{1 9 1 4 - 1 9 4 5}$ & $\mathbf{1 9 4 6 - 1 9 7 0}$ & $\mathbf{1 9 7 1 - 2 0 0 9}$ \\
$-\beta$ & 0.022 & 0 & 0.09 & 0.057 \\
$\rho$ & 0.597 & 0.23 & 0.74 & 0.53 \\
$-\beta /(1-\rho)$ & 0.052 & 0 & 0.34 & 0.12 \\
$-\beta /(1-\rho)-(r-\bar{g})$ & $\mathbf{0 . 0 2 6}$ & $\mathbf{- 0 . 0 3}$ & $\mathbf{0 . 3 9}$ & $\mathbf{0 . 0 7 2}$ \\
\hline
\end{tabular}

The first two rows report the calculated average real interest rate (approximated by the ratio between interest spending and outstanding debt) and the rate of growth of real GDP for each sub sample period. The third row expresses the growth of the debt-to-GDP ratio in the presence of a primary balance. The intensity of the fiscal rule is summarized by the estimated parameter $\beta$. However, in order to have fiscal sustainability, we have seen that Equation (9) requires a more stringent condition than a simply negative $\beta$ coefficient. This condition is binding if the coefficient calculated in the last row is positive.

If we exclude the period of the World Wars, when fiscal policy was clearly unsustainable due to exceptional military spending, we observe that our data support the view of fiscal sustainability for all the remaining sub sample periods.

During the period 1946-1970, the sustainability of fiscal policy was supported by the positive economic growth associated with low interest rates; the negative gap (-5\%) between the rate of interest and the rate of growth of GDP was in itself a condition ensuring a converging debt dynamic. Within this positive macroeconomic framework, the fiscal authorities were able to further support fiscal sustainability by implementing a very strong fiscal rule, with the highest estimated $\beta$. As a consequence, during this period we register the highest value for the threshold condition (last row of Table 3).

Turning our attention to the two remaining periods, 1862-1913 and 1971-2009, we observe that the reaction of fiscal authorities to the outstanding debt has been quite strong during recent decades ( $\beta=-0.057)$, and more intense compared to the period 1862-1913 ( $\beta=-0.022)$. In the late 20th century, the strict commitment to a sustainable debt has offset the poor economic performance and the high burden of servicing debt, summarized by a gap between the interest rate and the GDP growth rate of about 5 percentage points. As a consequence, although the macroeconomic setting was more favorable to fiscal consolidation in the early decades of the Italian State with respect to the recent ones, according to the estimated fiscal rule, the sustainability condition tells us that in recent decades a better performance was achieved compared to the 
period 1862-1913. How can we reconcile this positive picture with the dramatic effects on Italian public accounts resulting from the sovereign debt crisis? In the next section we delve into the comparison between the different historical periods to answer this apparent contradiction.

\section{Policy implications}

From our analysis on the debt dynamic in Italy in an historical perspective, there emerged not only remarkable recurrences and parallels between past and present but also important contrasts, which can help understand what policies could succeed in tackling the current debt crisis.

Among the four phases of the debt dynamic, two episodes of fiscal consolidation occurred after the wartime periods. In 1926 there was a significant reduction in war debts towards the United States and Great Britain which, along with robust economic growth and an inflationary process, helped curb the debt from $151 \%$ in 1924 to 93\% in 1926. Moreover, in 1926 the Fascist regime experienced a partial default by implementing forced consolidation of the public debt (the Littorio loan).

A new peak of 112\% was reached in 1942 which was, however, short-lasting. Indeed, by 1945 the debt-toGDP ratio had fallen to $68 \%$. As we noted above, this extraordinary performance was the consequence of extraordinary high inflation and commitment to a fiscal rule.

As to the remaining two periods, 1862-1913 and 1971-2009, in the previous section we saw that according to the sustainability condition, in recent decades there has been a very strong commitment to fiscal solvency. Nonetheless, by comparing the two periods, we have the impression that the former is an example of successful debt management, whereas the possible outcome of the current debt crisis is less clear. In order to appreciate the possible reasons motivating this different performance, we can start by comparing the level of the debt-to-GDP ratio, restricting the sample to the years 1871-1911 and 1971-2011. Since we are interested in having the debt dynamics in a single graph, we can consider the year of the peaks, 1894 and 1994, as the time zero (horizontal axis in Figure 6); it is then possible to describe the pattern of the debt-to-GDP ratio in the years preceding the peak (listed as negative numbers on the horizontal axis) and during the period after the peak (listed as positive numbers). 
Figure 6: debt-to-GDP ratio during the periods 1871-1911 (dashed line) and 1971-2011 (solid line)

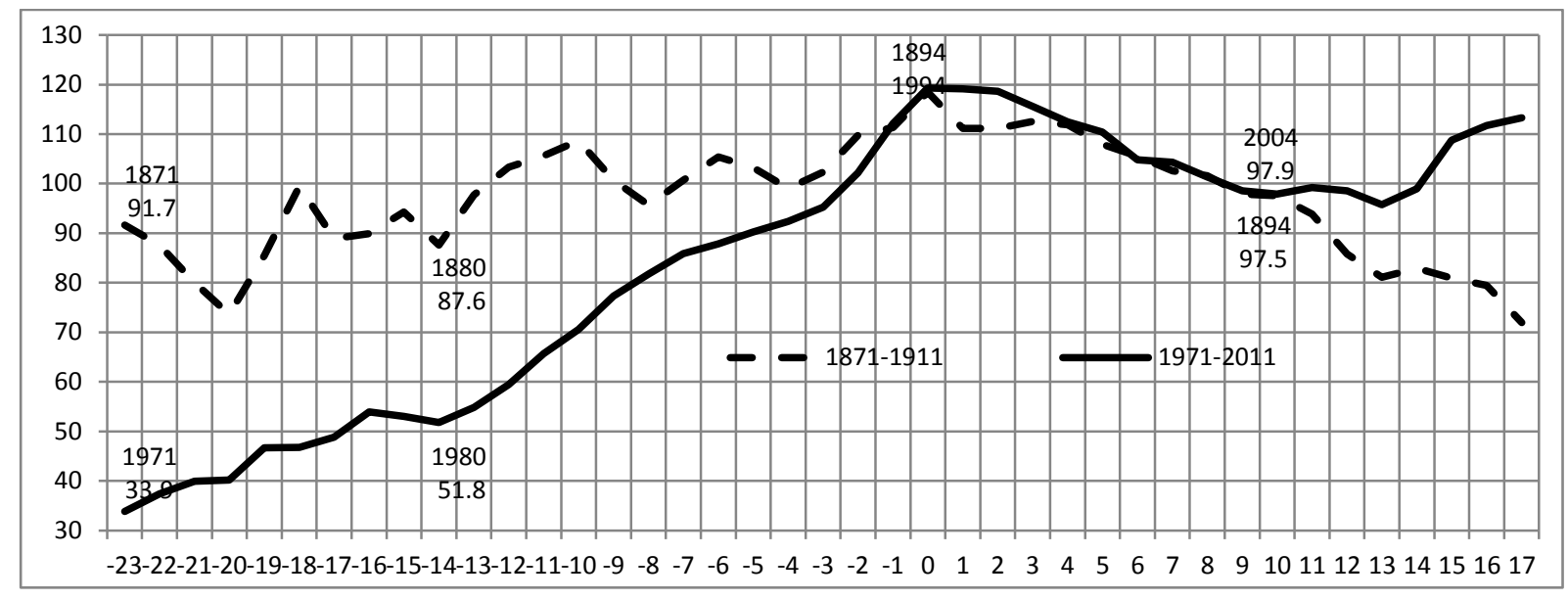

Source: data from Francese and Pace (2008), Baffigi (2011).

Hence the dashed line represents the yearly debt-to-GDP ratio starting from 1871 (time -23) until 1911 (time +17) going through 1894 (time 0). Similarly, the solid line displays the debt ratio during the period 1971

(time -23) until 2011 (time +17); also in this case, time zero is the year of maximum debt, i.e. 1994.

Figure 6 shows that, around the peaks, the level of the debt-to-GDP ratio was very similar in both the periods, 1871-1911 and 1971-2011, although important differences deserve to be commented upon. First, if we look at the twenty-three years preceding the peak, what is immediately striking is the enormous difference in the debt ratio at the beginning of the periods: in 1971 the debt ratio (about 34\%) was almost 60\% lower than in 1871 (about 92\%). Starting from 1980, the path of the debt-to-GDP ratio displays a very sustained growth, suggesting that governments were not conscious of the harm that would be done by excessive debt accumulation. The "this-time-is-different syndrome”, documented by Carmen Reinhart and Kenneth Rogoff (2009), may be a possible explanation for the pattern of Italian debt during the period 19811994 (Figure 6), suggesting the fading memory of successive Italian governments (each lasting in office for, on average, just eight months), which had not learnt the historical lessons on how to manage a sustainable fiscal policy until they were faced with a financial crisis. Second, the debt dynamic after the recorded maxima (1894 and 1994) is very similar during the first decade, when the dashed and solid lines are almost identical. If we were to stop the comparison at this point, the evidence would be perfectly in line with the estimated fiscal rule: thanks to the very high estimated $\beta$ coefficient, fiscal authorities were able, in 1994, to 
curb the debt dynamic, reaching, in ten years, a level similar to that recorded a century before, even in a worse macroeconomic setting and after an explosive trend in debt dynamics.

Unfortunately, starting from the tenth year from the peaks, there was a strong divergence in the debt-to-GDP ratios between the two periods. This might raise doubts about the reliability of our estimated fiscal rule.

However, we argue that this would be a erroneous conclusion, since fiscal sustainability is not a year-by-year concept, but has to be evaluated in the medium-long run (Charles Wyplosz, 2012). The estimated fiscal rule refers to the period 1971-2009, which experienced very different macroeconomic and institutional scenarios. On the one hand, on examining the entire period, we find support for sustainable debt management; on the other, when focusing on the very recent years, it can be appreciated how important the poorer macroeconomic dynamic has been in affecting the debt-to-GDP ratio.

To elucidate this latter point, we need to comment upon some further data. In Figure 7 we plot the annual change in the debt-to-GDP ratio, and restrict our analysis to the periods 1881-1911 and 1981-2011.

Figure 7: annual change in the debt-to-GDP ratio in the years preceding and following the maximum peak; comparison between periods 1881-1911 (dashed) and 1981-2011 (solid)

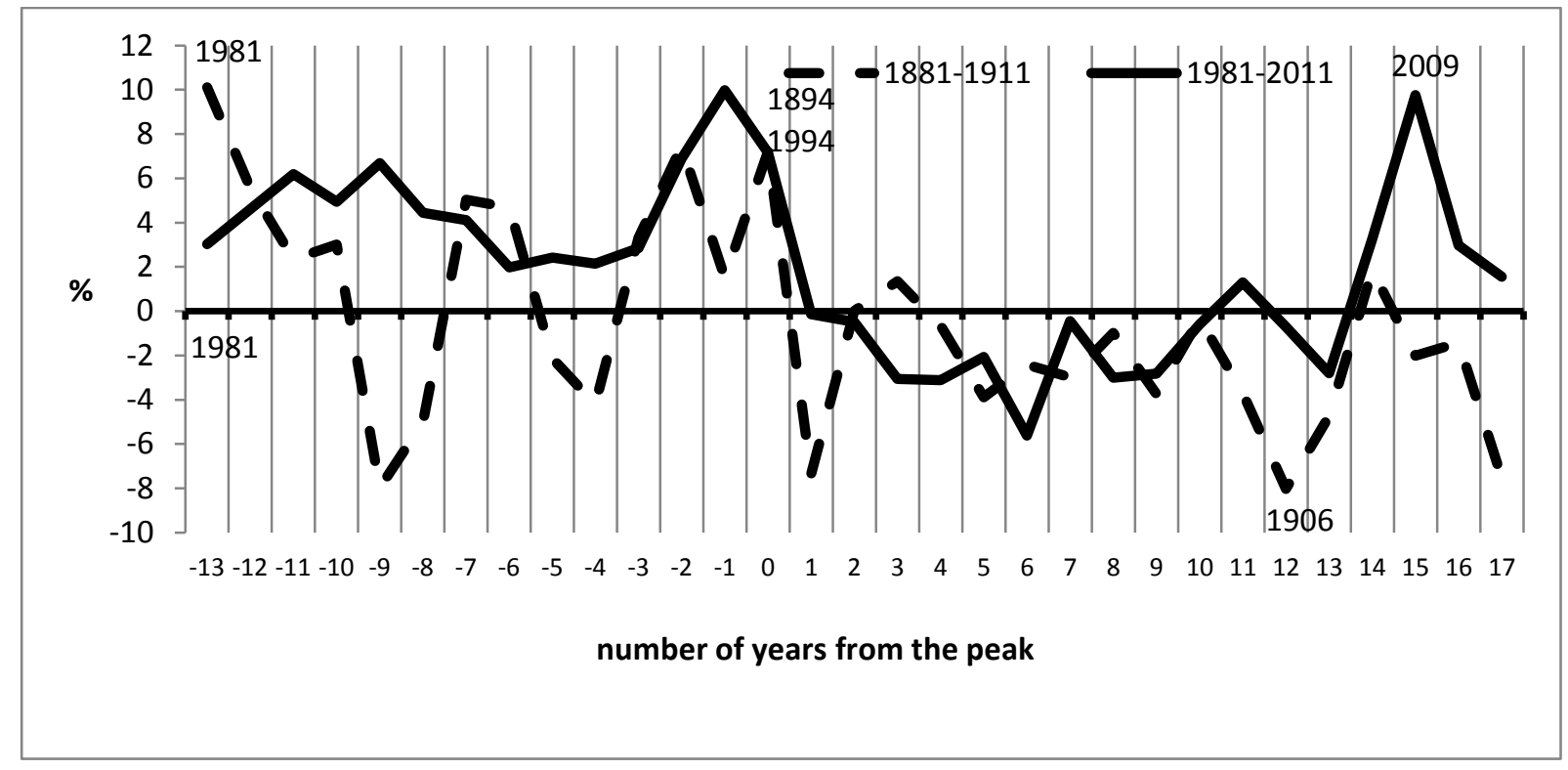

Source: data from Francese and Pace (2008), Baffigi (2011).

As already documented, the two recorded maxima in the debt-to-GDP ratio were almost identical, 118.5 and 119.3\% of GDP in 1894 and 1994, respectively, but the debt dynamics were very different, as shown in 
Figure 7. First, while in the last decade of the $19^{\text {th }}$ century debt contraction started before the peak (for instance the debt dynamic was negative during the years 1884-1886 and 1888-1890), during the period 19811994 the process of debt accumulation went on uninterrupted (this is consistent with the steep slope of the debt-to-GDP ratio already noted in Figure 6). Interestingly, the cumulative contraction of the debt-to-GDP ratio in the 10 years subsequent to the peaks amounted to 21 points during both periods. However, the debt reduction was mostly concentrated in the early years after the 1994 peak, whereas, after a sharp adjustment in 1895 (-7\%) it was more gradual after the episode recorded in 1894. As expected, what looks very different is the dynamic of the debt after the first decade from the recorded maximum, i.e. 1904-1911 and 2004-2011, which is clearly sustainable only for the first episode, when variations in the debt-to-GDP ratio were always negative. What can help to explain these different patterns?

Some features are common to both periods. First of all, fiscal stance was restrictive, with a commitment to run primary surpluses, as documented by the estimated fiscal rules. Moreover, a positive contribution to fiscal sustainability was given by a reduction in nominal interest rates, achieved, during the Giolitti period, by the decision (1906) to follow European countries in pursuing "rent conversion”, whereas the decision to become a founder-member of the EMU in 1999 was a major change for fiscal sustainability, with interest rates converging rapidly towards the European average. However, while the cost of debt, as a proportion of GDP, declined from 4.9 in 1894 to 3.2 in 1906, with a further reduction subsequent to "rent conversion" leading to a share of 2.2\% in 1912, the very high level of interest spending achieved in 1994 (10.3\% of GDP) declined to 6.7 when the EMU was established, to reach a minimum of 4.4\% of GDP in 2007.

Along with a higher burden of the interest payment on outstanding debt, a further explanation for one of the main causes of the unsuccessful debt consolidation observed in recent decades is the poorer economic performance compared to the Giolitti era. While on average there were no large differences between the nominal growth rate of GDP (excluding the years of the current contraction), the performance of real GDP has been very disappointing since the 1990s. In Figure 8 we compare the economic performance during the periods 1894-1913 and 1994-2013; again, we adopt the convention to set to zero the year of the peak (respectively 1894 and 1994), so that the first period is listed on the horizontal axis as running from time zero (1894) to time 19 (1913). 
Figure 8: annual real (left) and nominal (right) GDP growth rates in the years following the debt-to-GDP peak; a comparison between periods 1894-1913 (dashed) and 1994-2013 (solid)
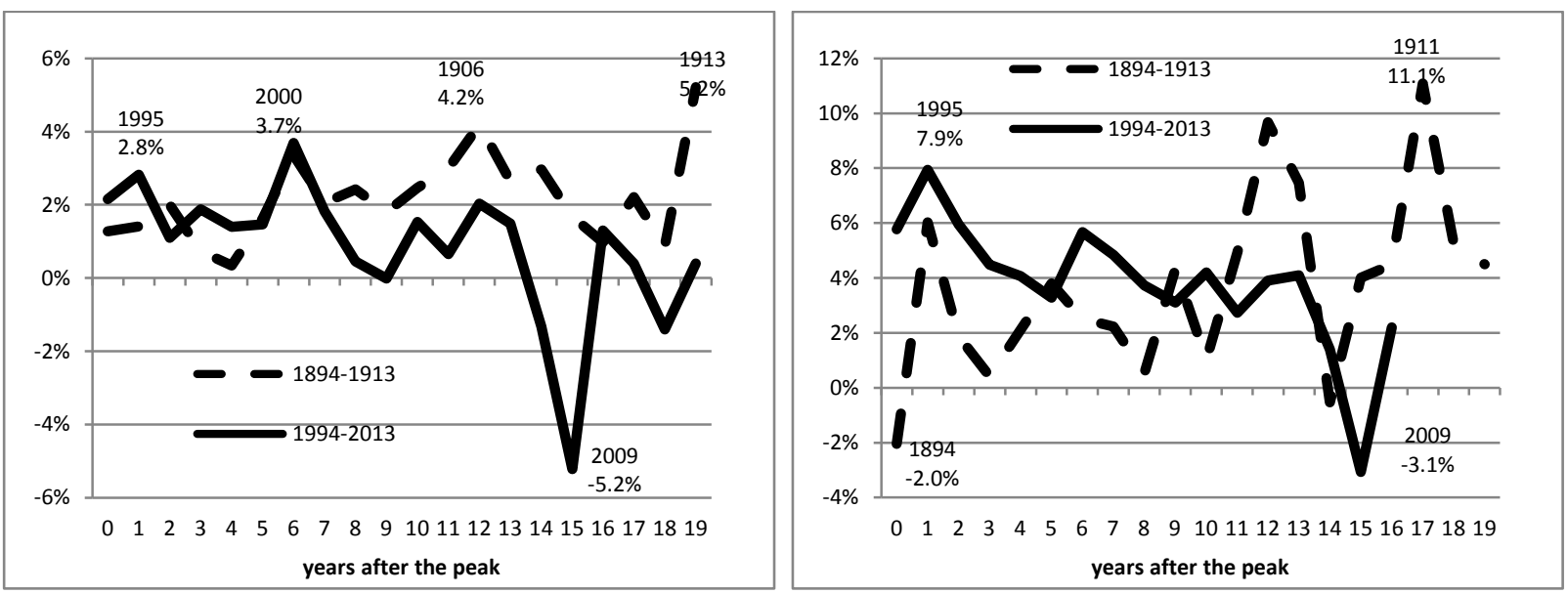

Source: data from Francese and Pace (2008), Baffigi (2011).

During the time span 1994-2000 the performance of the Italian economy in real terms (Figure 8, left panel), on average $2.1 \%$, was no worse than that recorded during the previous century (1.5\%). The growth rate amounted to $2.8 \%$ in 1995 , and peaked at $3.7 \%$ in 2000 . However, starting from the new millennium, real GDP growth slowed down, with a negative peak during the great recession (2009). By contrast, real GDP growth accelerated after 1900, reaching 4.2\% in 1906 and 5.2\% in 1913. When also accounting for the effect of inflation on economic performance, major differences arise. While GDP growth, in nominal terms (right hand panel of Figure 8), displays a clear upward trend during the period 1894-1913, going from a minimum of $-2 \%$ in 1894 to a maximum of about $11 \%$ in 1911, the opposite tendency has been recorded in recent years, with the growth rate declining from a peak of 7.8\% in 1995 to a lower bound of $-3.1 \%$ in 2009 . GDP growth in the years 1894-1913 was caused by the increase in foreign investment flows into Italy, which led to a reduction in interest rates. The abundance of financial resources, had positive effects on various sectors of the economy, resulting in sustained industrial growth, and an increase in consumption and prices (Stefano Fenoaltea, 2006). The increase in prices and hence inflation was also caused by the discoveries of new gold reserves, which led to an increase in world prices. Hence the Italian cycle during the years of the Giolitti belle époque was positively affected by international markets. Conversely, among possible causes of the poor economic performance in recent decades, it has been stressed elsewhere that the Italian economy was structurally inadequate to exploit the opportunities offered by the ICT revolution: small firm size, 
oppressive regulation and low level of human capital were the main factors proposed to explain the very poor productivity dynamic. In addition, despite the fact that during the 1990s many important structural reforms (privatization, banking and company law, pension schemes, wage policy) were launched, they were not sufficient to stimulate a veritable competitive market, and their effects were undermined by the inadequacy of the legal system and the burden of bureaucracy. ${ }^{42}$ Such large differences in the recent macroeconomic framework, compared to the Giolitti era, explain the difficulties encountered in managing fiscal consolidation in recent years.

The deterioration of public finances after the financial crisis starting in 2007, experienced by several European countries, means that fiscal sustainability in Italy cannot be achieved other than in a European framework. Among the policies so far adopted at the European level, some are certainly useful to pursue the reduction of sovereign debt spreads. The European Central Bank started, in September 2012, the Outright Monetary Transactions program, which is a bond-buying program, especially targeting for short-term maturities. A similar effect is achieved through the European Stability Mechanism, under which bonds are purchased both in primary and in secondary markets.

However, these measures alone cannot guarantee the sustainability of the Italian debt, and the involvement of the European institutions is absolutely necessary not only in requiring fiscal adjustment, to which Italian governments have been strongly committed, but also in promoting growth. Given the very high level of public debt in almost all the European countries far above the threshold set by the Maastricht Treaty, spurring growth should be the main concern of European institutions. In addition, we have seen that growth associated to moderate inflation can facilitate fiscal adjustment. Of course, participation in the EMU means that monetization of government debt is no longer a prerogative of national central banks but is the purview of the European Central Bank. Since even in Germany the level of public debt as a proportion of GDP is beyond $80 \%$, a moderate inflationary policy, aiming to sustain public investment and not current spending, could help the public finances of many European countries.

\section{Concluding remarks}

In this paper we analyzed the dynamic and effects of the Italian public debt on fiscal policy since Italian Unification in 1861. We tackled this task with two different approaches, namely using a historical and 
statistical analysis. However, a preliminary task was to compare different sources on the available data (GDP, taxation, public spending and public debt) and to reconstruct them.

The first part of the work was essentially an historical analysis, aimed at identifying the political elements and economic shocks (both domestic and international) which impacted upon the debt (and its dynamics) and its determinants. Historical reconstruction suggests that the current high level of public debt is not a unique event in Italian history (the peak reached in 1894 was almost identical to that of 1994), and that the debt crises may also terminate without resorting to default. In this sense it provided a valuable aid to interpreting the dynamics of the statistical series, contributing to analyze the sustainability of Italian public debt. To this end we followed the model approach by Bohn $(1998,2005)$ and Doi et al. (2011) and performed an analysis of the Italian series distinguishing four historical periods.

Various aspects of the comparative dynamics of debt and its economic determinants emerged, in particular the role of primary surpluses, inflation and growth for the reduction of fiscal imbalances in different historical periods. The time-series econometric analysis emphasized several interesting issues. First, according to the model approach à la Bohn, the dynamic of Italian debt in the last 150 years seems to be sustainable, with the exception of the two World War periods (1914-1945). Second, macroeconomic performance was particularly favorable to a sustainable fiscal policy during the economic miracle (1946'70). Finally, comparison between the late 19th century and recent decades shows that fiscal authorities were strongly committed to achieving fiscal sustainability in both periods, although during the latter period the effort by government leaders failed because of the worse macroeconomic framework, possibly influenced by more stringent European rules and by a lack of long-term planning at national level.

\section{APPENDIX}

\section{SOURCES OF DATA}

The measure of public debt is that officially recorded by Bank of Italy, Table TCCE0225, as reconstructed by Francese and Pace (2008). The monthly time series for the debt of the Italian general government sector is also partitioned into the three-level subsector structure defined by ESA95: Central Government, Local 
Government, Social Security funds. Since we use an annual data set, we refer to the level of debt recorded at 31/12 of each year.

As for the public deficit, we have no measure consistent with the definition of General Government (GG), since to our knowledge the only long time series of public expenditures is the one recently reconstructed by the State General Accounting Department which refers to the State Budget, a subsector of the GG which includes many, though not all, of the statistical units belonging to the Central Government sector (ESA95). The recently provided reconstruction of the time series of public spending (RGS, 2011) is from 1862 up to 2009. As to revenues, the only available time series, which refers to the State Budget, covers the period 1862-1967 (Ministero del Tesoro, 1967). ${ }^{43}$ Therefore, we collected, starting from 1968 to the present, the data for revenue items as officially recorded in the Rendiconto Generale dello Stato (General Statement of State Accounts, Camera dei Deputati, several years), so that we have a complete data set containing the level of debt, public spending and revenues, all at current prices. In addition, since RGS (2011) also provides a measure of public spending at 2009 prices, we are able to calculate the deflator of public spending, which can be used to convert to 2009 prices all the public finance variables. It should be stressed that our measure of the public deficit is consistent with the net borrowing monitored by National Accounts for the European Union excessive deficit procedure, since we exclude from the deficit the financial aggregates pertaining to debt reimbursement (i.e. final revenues and expenditures). Therefore, we are able to compare a measure of the deficit, as approximated by data recorded in the State Budget, with the time course of Central Government debt starting from $1862 .{ }^{44}$ All the budget data are annual and collected on a fiscal year basis. Fiscal years are calendar years for most of the sample, with the exception of 1884-1965, when the fiscal year dated $t$ covered the period from July of calendar year $t-1$ to June of year $t$. Following RGS (2011) we converted to calendar years, summing half of the spending (revenues) recorded in two subsequent fiscal years, assuming in each fiscal year spending (revenues) are equally distributed.

Finally, as for GDP, there are several reconstructions in the literature covering different periods. The standard reconstruction of Italian National Accounting was published in 1957 by the Italian National Institute of Statistics (ISTAT) which covered a long period, from 1861 to 1956 . The ISTAT time series formed for many years the basis of studies and debate on the Italian economy. Moreover, since their 
publication, ISTAT series have undergone several revisions (Giorgio Fuà, 1969) because they were inconsistent on several accounts, and information on methods and sources used to collate data were not clear. At the end of the 1980s, the Bank of Italy promoted a completely new reconstruction of Italian National Accounting, whose results were published in four volumes edited by Guido Rey (1992, 2000). The revision concerns four benchmark years $(1891,1911,1938,1951)$ and involved scholars such as Stefano Fenoaltea for industry, Giovanni Federico for agriculture, and Vera Zamagni and Patrizia Battilani for services. These series were then subject to further revisions (Fenoaltea, 2005, 2006; Federico, 2003; Malanima, 2006). Of extreme importance was the reconstruction of nominal GDP for the period 1891-1990 by Nicola Rossi, Andrea Sorgato and Gianni Toniolo (Rossi et al., 1993), which has long been the basis for analyzing the national debt-to-GDP ratio. In 2011 a new series of GDP at current and constant prices was estimated by a research group coordinated by Alberto Baffigi (Baffigi, 2011).

For our analysis we decided to use this last series because it covers the entire period we examined (18612010), while the Rossi et al. (1993) series covers a shorter period of time, from 1891 to 1990.

Thus in our paper we analyzed debt sustainability in Italy using a unique source of data for the GDP. Moreover, in figure A1, we show differences in the ratio of debt to GDP by using the series of Rossi et al. (1993), as well as those of Baffigi (2011).

Figure A 1: the ratio of public debt to GDP. Comparison between estimations made by Rossi et al (1993) and Baffigi (2011)

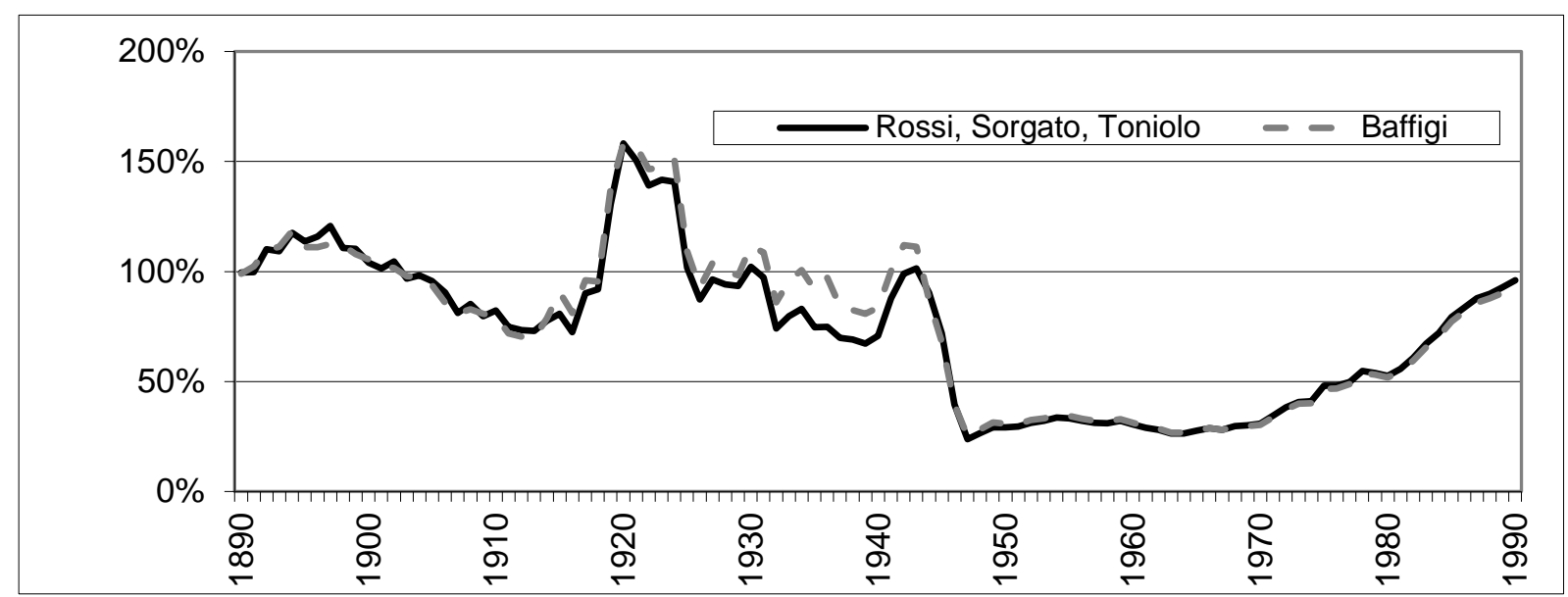

Source: Data taken from Francese and Pace (2008), Rossi et al. (1993), Baffigi (2011). 
The measure of GDP used to construct the debt-to-GDP ratio marginally influences the dynamics of the ratio, whereas it has the effect of raising it during the World Wars, as confirmed by the comparison between our measure of the debt ratio and that obtained by using the GDP estimated by Rossi et al. (1993). Hence the new GDP series has introduced important changes with respect to Italian economic performance during WWI, as well as during the Great Depression (for details, see Baffigi, 2011). By contrast, if we were to employ ISTAT series of nominal GDP, the differences would be much higher. 


\section{References}

Alesina, Alberto and Roberto Perotti. "Fiscal Expansions and Adjustments in OCED Countries.” Economic Policy 10, (1995): 207-248.

Angeloni, Ignazio and Luca Dedola. "From the ERM to the EURO: new evidence on economic and policy convergence among EU countries”, European Central Bank Working Papers, No 4, May 1999.

Artoni, Roberto, and Sara Biancini. “Il debito pubblico dall’Unità a oggi.” In Storia economica d’Italia , edited by Pierluigi Ciocca and Gianni Toniolo. Rome-Bari: Laterza, 2004.

Asso, Pier Francesco (1993), L'Italia e i prestiti esteri 1919-1931, Rome-Bari, Laterza.

Baffigi, Alberto. “Italian National Accounts, 1861-2011”, Banca d’Italia Economic History Working Papers, No.18, Rome, October 2011.

Balassone, Fabrizio, Maura Francese and Angelo Pace. "Public debt and economic growth in Italy", Banca d’Italia Economic History Working Papers, No. 11, Rome, October 2011.

Bartoletto, Silvana, Bruno Chiarini and Elisabetta Marzano. “The Sustainability of Fiscal Policy in Italy: A Long-Term Perspective”, CESifo Working Paper No. 3812, CESifo Group Munich, 2012. Basile, Raffaella, Bruno Chiarini and Elisabetta Marzano. “Can we Rely upon Fiscal Policy Estimates in Countries with Unreported Production of 15 Per Cent (or more) of GDP?”, CESifo Working Paper Series No.3521, CESifo Group Munich, 2011.

Bayoumi, Tamim and Barry Eichengreen. "Shocking Aspects of European Monetary Unification.” In Adjustment and Growth in the European Monetary Union, edited by Francisco Torres and Francesco Giavazzi, Cambridge, Cambridge University Press, 1993.

Blanchard, Olivier, Jean-Claude Chouraqui, Robert Hagemann and Nicola Sartor. “The sustainability of fiscal policy: new answers to an old question.” OECD Economic Studies, 15, Autumn, 1990.

Bohn, Henning. “The Behavior of U.S. Public Debt and Deficits.” The Quarterly Journal of Economics, August, (1998): 949-963. 
_ . "The sustainability of fiscal policy in the United States”, CESifo Working Paper 1446, 2005. . “Are stationary and Cointegration Restrictions really necessary for the Intertemporal Budget

Constraint?” Journal of Monetary Economics, 54 (7),(2007): 1837-1847.

Boltho, Andrea. “Disavanzo pubblico e strategie di rientro in alcuni paesi europei.” In Il Disavanzo Pubblico in Italia: Natura Strutturale e Politiche di Rientro, edited by Ente Einaudi Bologna, il Mulino, 1992.

Bordo, Michael, Barry Eichengreen, Daniela Klingebiel, Maria Soledad Martinez-Peria. “Is the crisis problem growing more severe?” Economic Policy, 16, April, (2001): 51-82.

Bordo, Michael and Hugh Rockoff. "The gold standard as a "good housekeeping seal of approval”.” The Journal of Economic History, 56 (2), (1996): 303-316.

Buti, Marco, and André Sapir, eds. Economic Policy in EMU-A Study by the European Commission Services. Oxford: Oxford University Press, 1998.

Camera dei Deputati. Rendiconto Generale della Amministrazione dello Stato:, Conto del Bilancio. Rome, several years.

Chalk, Nigel and Richard Hemming. “Assessing fiscal sustainability in theory and practice.” IMF Working Paper, WP/00/81, April 2000.

Ciocca Pierluigi. Ricchi per sempre? Una storia economica d'Italia (1796-2005). Torino: Bollati Boringhieri, 2007.

Conti, Giuseppe. “Italian government debt sustainability in the long run, 1861-2000”. In

Government debts and financial markets in Europe, 209-223 edited by Fausto Piola Caselli, 209223. London: Pickering \& Chatto, 2008.

Conte, Leandro, ed. Le banche e l'Italia. Crescita economica e società civile. Rome: Bancaria Editrice, 2011.

Cotula, Franco. “L’attuazione della politica monetaria in Italia.” In La politica monetaria in Italia Obiettivi e strumenti, edited by Franco Cotula, 473-510. Bologna: Il Mulino, 1989. 
Cotula, Franco, and Luigi Spaventa. “La politica monetaria tra le due guerre 1919-1935”. In Collana storica della Banca d'Italia- La Banca d'Italia. Sintesi della ricerca storica 1893-1960 edited by Franco Cotula, Marcello De Cecco, and Gianni Toniolo, 209-310. Rome-Bari: Laterza, 2003.

Crafts, Nicholas and Marco Magnani. “The golden age and the second globalization in Italy.” Banca d’Italia Economic History Working Papers, No.17, Rome, October 2011.

De Cecco, Marcello. “The Italian national debt conversion of 1906”. In Public debt management: theory and history edited by Dornbusch Rudiger, and Mario Draghi, 263-284. Cambridge: Cambridge University Press, 1990.

. L'Italia e il sistema finanziario internazionale 1919-36. Bari: Laterza, 1993. “L’Italia e il sistema finanziario internazionale 1860-1936”. In Collana storica della Banca d'Italia- La Banca d'Italia. Sintesi della ricerca storica 1893-1960 edited by Franco Cotula, Marcello De Cecco, and Gianni Toniolo, 3-58. Rome-Bari: Laterza, 2003.

De Nardis, Sergio, ed. Le Privatizzazioni italiane, Bologna: il Mulino, 2000.

Doi, Takero, Takeo Hoshi and Tatsuyoshi Okimoto. “Japanese government dent and sustainability of fiscal policy.” NBER Working Paper No.17305, Cambridge MA, August 2011.

Dornbusch, Rudiger and Mario Draghi, eds. Public debt management: theory and history. Cambridge: Cambridge University Press, 1990.

Eichengreen, Barry. “Is Europe an Optimum Currency Area?” In The European Community after 1992, edited by Borner S. and H. Grubel , London, The MacMillan Press Limited, 1992.

Eichengreen, Barry, and Marc Flandreau. “The geography of the gold standard”. In Currency convertibility: the gold standard and beyond, edited by Jorge Braga de Macedo, Barry Eichengreen, and Jaime Reis, 113-143. London: Routledge, 1996a.

Eichengreen, Barry, and Marc Flandreau, eds. The gold standard in theory and history. London and New York: Routledge, 1996b. 
Emerson, Michael, Daniel Gros, Alexander Italianer , Jean Pisani-Ferry and Horst Reichenbach, eds. One Market, One Money-An Evaluation of the Potential Costs and Benefits of Forming and Economic and Monetary Union. Oxford: Oxford University Press, 1992.

Ente Einaudi, ed. Il disavanzo pubblico in Italia: natura strutturale e politiche di rientro. Bologna: il Mulino, 1992.

Ercolani, Paolo. “Documentazione statistica di base”. In Lo sviluppo economico in Italia. Vol. 3, edited by Giorgio Fuà, 380-460. Milano: Franco Angeli, 1969.

Fausto, Domenicantonio. “La politica fiscale dalla prima guerra mondiale al regime fascista.” In Ricerche per la storia della Banca d’Italia. Vol. II. Rome-Bari: Laterza, 1993.

Federico, Giovanni. “Le nuove stime della produzione agricola italiana, 1860-1910: primi risultati ed implicazioni.” Rivista di Storia Economica, no. IXX (2003): 359-82.

Feldstein, M. “The Political Economy of the European Economic and Monetary Union: Political Sources of an Economic Liability.” NBER Working Paper, No. 6150, Cambridge MA, 1997a. Feldstein, M. “EMU and International Conflict.” Foreign Affairs, November/December (1997b): 60-73.

Fenoaltea, Stefano. “The Growth of the Italian Economy, 1861-1913: Preliminary Secondgeneration Estimates.” European Review of Economic History 9 (2005).

Fenoaltea, Stefano. L’economia italiana dall’Unità alla Grande Guerra. Bari: Laterza, 2006. Francese, Maura, and Angelo Pace . “Il debito pubblico italiano dall’Unità a oggi. Una ricostruzione della serie storica.” Banca d’Italia, Questioni di economia e finanza, No. 31, Rome, October 2008. Frascani, Paolo. Le crisi economiche in Italia dall'Ottocento a oggi. Roma-Bari: Laterza, 2012 Fratianni, Michele, and Franco Spinelli. Storia monetaria d'Italia. Lira e politica monetaria dall'Unità all'Unione Europea. Milan: Etas, 2001.

Fuà, Giorgio, ed. Lo sviluppo economico in Italia. Milan: Franco Angeli, 1969.

Giavazzi, Francesco and Luigi Spaventa eds. High Public Debt: The Italian Experience. Cambridge: Cambridge University Press, 1988. 
Giavazzi, Francesco and Marco Pagano. “Confidence crises and public debt management.” In Public debt management: theory and history edited by Dornbusch Rudiger, and Mario Draghi. Cambridge: Cambridge University Press, 1990.

Giavazzi, Francesco and Francisco Torres, eds. Adjustment and Growth in the European Monetary Union. Cambridge: Cambridge University Press, 1993.

Guarino, Giuseppe, and Gianni Toniolo, eds. La Banca d'Italia e il sistema bancario 1919-1936. Rome-Bari: Laterza, 1993.

Maddison, Angus. Monitoring the world economy 1820-1992. Paris: OECD, 1995.

Makinen Gail E., and Thomas G. Woodward. "Funding crises in the aftermath of World War I”. In Public debt management: theory and history, edited by Robert Dornbusch, and Mario Draghi. Cambridge: Cambridge University Press, 1990.

Malanima, Paolo. “Alle origini della crescita in Italia 1820-1913.” Rivista di Storia Economica, no. XII (2006): 306-330.

Masera, Rainer. Disavanzo Pubblico e Vincolo di Bilancio. Milano: Edizioni di comunità, 1979. Ministero del Tesoro, Ragioneria Generale dello Stato. Il bilancio dello Stato Italiano dal 1862 al 1967. Vol. II. Rome: Istituto Poligrafico dello Stato, 1967.

Morcaldo, Giancarlo. La Finanza Pubblica in Italia, Bologna: il Mulino, 1993.

Nardozzi Giangiacomo, ed. I Difficili Anni ’70. Milan: Etas Libri, 1980.

Panteghini, Paolo, and Franco Spinelli. “Un “buon” rientro del debito pubblico: l’Italia tra '800 e '900.” In Politiche macroeconomiche, gestione del debito pubblico e mercati finanziari, edited by Michele Bagella and Luigi Paganetto, Bologna: il Mulino, 2002.

Pedone Antonio. “Alle origini del persistente alto livello del debito pubblico italiano” Mimeo, available online at http://www-3.unipv.it/websiep/2012ri2.pdf, 2012.

Persson, Torsten and Guido Tabellini. Macroeconomic Policy, Credibility and Politics, Chur, Switzerland: Harwood Academic Publishers, 1989. 
Persson, Torsten and Guido Tabellini. Political Economics. Explaining Economic Policy. Cambridge MA: MIT Press, 2002.

Reinhart, Carmen M., and Kenneth S. Rogoff . This time is different. Eight centuries of financial folly. Princeton: Princeton University Press, 2009.

Reinhart, Carmen M. “A series of unfortunate events: common sequencing patterns in financial crises.” Rivista di Politica Economica, October-December (2011):11-36.

Ragioneria Generale dello Stato. “La spesa dello Stato dall’Unità d’Italia.” Studi e Pubblicazioni, Rome, 2011.

Repaci, Francesco A. La finanza pubblica italiana nel secolo 1861-1960. Bologna: Zanichelli, 1962.

Rey, Guido M., ed. I conti economici dell'Italia.Una stima del valore aggiunto per il 1911. Rome: Laterza, 1992.

. I conti economici dell'Italia.Il valore aggiunto per gli anni 1891, 1938, 1951. Rome: Laterza, 2000.

Rossi, Nicola, Andrea Sorgato, and Gianni Toniolo. “I conti economici italiani: una ricostruzione statistica, 1890-1990.” Rivista di Storia economica, no. 10 (1993).

Roubini Nouriel and Jeffrey. Sachs. "Political and economic determinants of budget deficits in the industrial democracies.” European Economic Review, 33, (1989): 903-38.

Salvemini, Giancarlo. “Il finanziamento del Tesoro.” In La politica monetaria in Italia. Obiettivi e strumenti, edited by Franco Cotula, 249-79. Bologna, il Mulino, 1989.

Salvemini, Giancarlo, and Vera Zamagni. "Finanza pubblica e indebitamento tra le due guerre mondiali: il finanziamento del settore statale”. In Ricerche per la storia della Banca d'Italia. Vol. 2. Problemi di finanza pubblica tra le due guerre. 1919-1939. Roma-Bari: Laterza, 1993.

Salvemini Maria Teresa. Le Politiche del Debito Pubblico. Bari: Laterza, 1992.

Tabellini, Guido. “Central Bank reputation and the monetization of deficits: The 1981 Italian monetary reform.” Economic Inquiry, vol. 25, no. 2 (1987): 185-200. 
Tattara, Giuseppe. “Paper money but a gold debt: Italy on the gold standard.” Exploration in Economic History, no. 40 (2003): 122-142.

Toniolo, Gianni.“La Banca d’Italia e l’economia di Guerra 1914-1919.” In Collana storica della Banca d'Italia- La Banca d'Italia. Sintesi della ricerca storica 1893-1960 edited by Franco Cotula, Marcello De Cecco, and Gianni Toniolo. Rome-Bari: Laterza, 2003.

Toniolo, Gianni, Leandro Conte, and Giovanni Vecchi. “Monetary Union, institutions and financial market integration: Italy, 1862-1905.” Explorations in Economic History, no. 40 (2003), 443-461. Toniolo, Gianni, and Piero Ganugi. "Il debito pubblico italiano in prospettiva secolare (18761947).” In Il Disavanzo Pubblico in Italia: Natura Strutturale e Politiche di Rientro, edited by Ente Einaudi. Bologna: il Mulino, 1992.

Trehan, Bharat and Carl Walsh. “Common Trends, The Government Budget Constraint, and Revenue Smoothing.” Journal of Economic Dynamics and Control 12, June/September (1988): 425-44.

Trehan, Bharat and Carl Walsh. "Testing Intertemporal Budget Constraints: Theory and Applications to U.S. Federal Budget and Current Account Deficits.” Journal of Money, Credit and Banking 23, no. 2 (1991): 210-23.

Valli Vittorio. L'Economia e la Politica Economica Italiana (1945-1979). Milan: Etas-Libri, 1979. Zamagni, Vera. “Debito pubblico e creazione di un nuovo apparato fiscale nell’Italia unificata (1861-76).” In Il Disavanzo Pubblico in Italia: Natura Strutturale e Politiche di Rientro, edited by Ente Einaudi. Bologna: il Mulino, 1992.

Zamagni, Vera. “Il debito pubblico italiano 1861-1946: ricostruzione della serie storica.” Rivista di Storia economica, no. 3 (1998).

Wyplosz,Charles. "Fiscal rules: Theoretical issues and historical experiences.” NBER Working Paper No.17884, Cambridge, MA, March 2012. 
${ }^{1}$ For example, Zamagni (1998) considers the evolution of the public debt from 1861 to 1946, uses the series of Rossi et al. (1993) for the period 1890-1946 while for the period 1861-1889 she uses Vitali's, based on the old ISTAT series (Ercolani, 1969). In Artoni and Biancini (2003) the analysis starts from 1885 to 2001: for the first period 1885-1913 they use Zamagni (1998) to calculate the GDP/debt ratio while for the following period they use the GDP series estimated by Rossi et al (1993). For more details on the latter series see the Appendix.

${ }^{2}$ About the weakness of the ISTAT series see, amongst others, Malanima (2006) and Fenoaltea (2005, 2006).

${ }^{3}$ Balassone et al. (2011) provide an interesting description of the main differences in fiscal policy during the two episodes of large indebtedness observed in the late 19th and 20th centuries. For a recent comment on the persistently high level of public debt during the 150 years of the Italian State compared to the dynamic observed in other developed countries see Pedone (2012).

${ }^{4}$ Interestingly, our phases are consistent with the periodization of financial history adopted by Bordo et al. (2001).

${ }^{5}$ This figure is consistent with the reconstruction by Zamagni (1998). See also Artoni and Biancini (2004).

${ }^{6}$ From 1869 to 1876, the share of interest spending on the total expenditure was on average more than 35\%, with a peak of $42 \%$ in 1870 .

${ }^{7}$ The Rothschilds kept a large stock of Italian debt in their portfolios. They feared that a request for additional funds on the international capital market would reduce rendita prices (De Cecco, 1990).

${ }^{8}$ Until World War I, Italy was legally on a bimetallic exchange rate regime for 15 years (1861-66 and 1883-1893), but the actual period of effective lira convertibility was seven years (Tattara, 2003; Toniolo et al. 2003). For a deep analysis on the international gold standard see Eichengreen and Flandreau (1996a, b); Bordo and Rockoff (1996).

${ }^{9}$ Another important measure to tackle the increasing budget imbalance was the expropriation of church property in 1866.

${ }^{10}$ The Banca Nazionale was forced by the government to lend 250 million lire to the Treasury (Zamagni, 1992), and this can be assimilated to an episode of financial repression similar to those commented upon for the Bretton Woods system by Reinhart (2011).

${ }^{11}$ For details see De Cecco (2003) and Toniolo et al. (2003).

${ }^{12}$ Among factors that aggravated the context of political instability as well as Italian public finance, were the taking of Rome (1870) and the transfer of Italy’s capital from Florence to Rome.

${ }^{13}$ In 1893 the Banca Romana, one of the issuing banks, went bankrupt. For details, see amongst others Conte (2011) and Frascani (2012). For an historical summary of banking crises in Italy see Reinhart and Rogoff (2009).

${ }^{14}$ For details on 1906 Italian conversion see De Cecco (1990), Panteghini and Spinelli (2002). 
${ }^{15}$ See Bordo et al. (2001).

${ }^{16}$ For example, for the third and fourth national loans, less than fifty per cent of the nominal value was collected in cash. While the first three issued national loans were redeemable, the last were consolidated (see Repaci, 1962).

${ }^{17}$ The National Institute for Foreign Exchange was established in December 1917 in order to control the currency transactions. After the end of the monopoly in 1919, it had only supervisory tasks in the currency markets.

${ }^{18}$ Conti (2008), Fausto (1993), Salvemini and Zamagni (1993).

${ }^{19}$ Zamagni (1998).

${ }^{20}$ This episode can be considered, consistently with Reinhart and Rogoff (2009), as a partial default, seeing that the Italian government, through the Littorio loan, forced its creditors to accept longer repayment. For further details see Makinen and Woodward (1990) and Toniolo and Ganugi (1992).

${ }^{21}$ The idea of returning to the gold standard met with almost full consensus. Britain returned to the gold standard in 1924, while France in 1926 (see, amongst others, De Cecco, 1993).

${ }^{22}$ Through the creation of the Institute for Industrial Reconstruction (IRI), the Italian State acquired significant holdings in many companies belonging to different sectors of the economy. This was the beginning in Italy of the complex mechanism of state-controlled enterprises which would only end after the signing of the Treaty of Maastricht. For further details about the new banking act, see Guarino and Toniolo (1993).

${ }^{23}$ The regions in the south were occupied by the Allied forces while northern Italy by Germans, until April 1945.

${ }^{24}$ The AM-lire (Allied Military Currency) were issued by the Allied Military Government of Occupied Territories until March 1946. With regard to the external purchasing power of the lira, on the eve of the war the official exchange rate was 19 lire to the dollar. When the Allies landed in Sicily, the exchange rate was about 45-50 lire per dollar. With a decision that would be considered too harsh, the Allied imposed an exchange rate of 100 lire (Fratianni and Spinelli, 2001). Several "exceptional" costs were ascribed to occupation of the territory. We should mention the war indemnity of 180 billion paid to the Germans and 145 billion in expenses incurred by the Allies (Repaci, 1962).

${ }^{25}$ From 1943, Italy had been able to rely on foreign economic aid, such as the UNRRA relief economic plan (United Nations Relief and Rehabilitation Administration), which was largely replaced in 1948 by the Marshall plan.

${ }^{26}$ See amongst others Ciocca (2007).

${ }^{27}$ See, for instance, Nardozzi (1980) and Valli (1979).

${ }^{28}$ Data from the Bank of Italy, reported in Masera (1979), show that in the period 1949-70, the returns on financial assets (government securities, bonds and stocks) were all positive. By contrast, in the first half of the 1970s, 
government bonds reported a negative real return equal to $-11.3 \%$, the returns in short-term bonds were $-9.3 \%$ and those in stocks fell by more than $15 \%$.

${ }^{29}$ See also, amongst others, Giavazzi and Pagano (1990).

${ }^{30}$ For an analysis of public deficits in the Western economies in the 80s, see amongst others Boltho (1992) and Wyplosz (2012).

${ }^{31}$ For a detailed analysis of the monetary policy in Italy and money-financing of fiscal deficit in the period 1970-1987 see Cotula (1989) and Salvemini (1989). On the 1981 Italian monetary reform, see Tabellini (1987) amongst others.

${ }^{32}$ See, the Bank of Italy data in Morcaldo (1993).

${ }^{33}$ See the papers in Ente Einaudi (1992).

${ }^{34}$ Much has been written on the relationship between government structure and fiscal policy. See the papers in Giavazzi and Spaventa (1988) and Dornbusch and Draghi (1990) for historical and theoretical considerations. See also Roubini and Sachs (1989) and Persson and Tabellini (1989; 2002).

${ }^{35}$ Between 1992 and 1999, privatization in Italy produced a value equal to 12.3\% of 1992 GDP. For a detailed analysis see the papers in De Nardis (2000).

${ }^{36}$ There exists an enormous literature on the costs and benefits of EMU, the Stability and Growth Pact etc. See, for instance, the very large number of papers of the European Commission. We quote Emerson et al. (1992) and Buti and Sapir (1998). Views on EMU address three main questions. Does the single European currency satisfy "Optimum Currency Area” (OCA) conditions? Do heterogeneous economic and financial structures create undesired differences in the local impact of the single monetary policy? Do the area-wide considerations generate conflicts in the decisionmaking process of the European Central Bank (ECB)? On these issues see, amongst others, Eichengreen (1992), Bayoumi and Eichengreen (1993), Feldstein (1997 a,b) and Angeloni and Dedola (1999) just to cite a few.

${ }^{37}$ The government budget identity can be stated in terms of real variables, nominal variables, or relative to a scale variable, like GDP. Accordingly, the appropriate definition of the accumulation factor, $i$, would be: the real interest rate, the nominal interest rate, the real interest rate net of the economic growth rate. The assumption of a constant interest rate simplifies the algebra, and it is the most common in the literature (Bohn, 2007).

${ }^{38}$ See Bartoletto et al. (2012) for an application of this approach to Italian data.

${ }^{39}$ However, if the debt-to-GDP ratio is a variable integrated of order one, I(1), the policy rule would imply cointegration between debt and primary surplus, satisfying the sufficient condition, in the presence of a constant interest rate, stated by Trehan and Walsh (1988). See Bartoletto et al. (2012) for an analysis of Italian data. 
${ }^{40}$ In the presence of serially correlated residuals the estimated standard errors, and hence t-statistics, are not reliable. Without including the AR(1) in the fiscal rule of Equation 4, the Durbin Watson statistic would indicate positive serial correlation. Breusch-Godfrey Serial Correlation LM test can be used for AR(1) and higher orders of serial correlation in models with lagged dependent variables.

${ }^{41}$ Appropriate impulse dummies have been included to account for the outliers emerging in the graphical analysis of the regression residuals. LM tests indicate the existence of a serial correlation for the period 1914-1945, and, to a lesser extent, for 1946-1970. However, LM tests show that the null hypothesis of no serial correlation up to lag 3 is not rejected for the remaining two periods, 1862-1913 and 1971-2009, which we will principally address in the next Section.

${ }^{42}$ See amongst others Crafts and Magnani (2011). To complete the picture, two further issues should be mentioned: the resurgence of dualism between northern and southern regions; myopic management of fiscal policy, with an insane tolerance of tax evasion. These two issues would require in-depth analysis which goes beyond the scope of the present paper.

${ }^{43}$ For the time series of revenues until 1967 see Ministero del Tesoro (1967), Table 5, in particular the row “Operazioni Finali”, pp.140-170.

44 There is no substantial difference between the General Government (total) debt and the debt accumulated by the Central Government. 